\title{
Morphological trends and new species of Cyphaspis (Trilobita, Otarioninae) in the Devonian of Morocco, Turkey, Germany and Belgium
}

\author{
Allart P. VAN VIERSEN ${ }^{1 *} \&$ DieTER HOLLAND ${ }^{2}$
}

1. Natuurhistorisch Museum Maastricht, De Bosquetplein 6-7,6211 KJ Maastricht, The Netherlands; apvanviersen@gmail.com 2. Sandstrasse 26, 31241 Ilsede, Germany; dihol@t-online.de

* corresponding author

\begin{abstract}
New species of the otarionine trilobite Cyphaspis are recorded from Pragian to Givetian localities in Morocco and Belgium. The material carries a wealth of new insights into the diversity of Cyphaspis during the Devonian. In an attempt to bring structure to the vast assortment of species, selected taxa are clustered into three informal groups that need to be validated in future analyses: the agayuara group for Siluro-Devonian species that retain a "primitive" morphology, the hamidi group for comparatively small, Emsian to Eifelian species with convergences on Otarion, and the ceratophthalmus group which encompasses the type species of Cyphaspis, C. ceratophthalmus (Goldfuss, 1843), and similar species. Morphological trends in each of the groups are briefly elaborated on. Twelve new species are recorded from Morocco: C. bluhmi sp. nov., C. eximia sp. nov., $C$. foumzguidensis sp. nov., $C$. heisingi sp. nov., $C$. ihmadii sp. nov., $C$. juergenhollandi sp. nov., $C$. khraidensis sp. nov., $C$. kippingi sp. nov., C. lerougei sp. nov., C. maharchensis sp. nov., C. smeenki sp. nov., C. tadachachtensis sp. nov. One additional species, $C$. boninoi sp. nov., is recorded from Belgium. Topotypical material of $C$. ceratophthalmus from Germany and the holotype of $C$. goerlichi (Haas, 1968) from Turkey are illustrated for comparisons to the other species. The holotype of $C$. ceratophthalmus could not be traced and a neotype is designated.
\end{abstract}

KEYWORDS: Systematic palaeontology, Aulacopleuridae, Devonian, Morocco, Germany, Belgium, Turkey

\section{Introduction}

The systematics and ontogeny of the Otarioninae were subjected to the comprehensive studies of Adrain \& Chatterton $(1994,1995,1996)$ who underlined the importance of heterochrony to the evolution of the nominal Otarionini. The tribe's chief genera in sheer species numbers are the Siluro-Devonian Cyphaspis Burmeister, 1843 and Otarion Zenker, 1833 which were regarded as sister taxa by Adrain \& Chatterton (1994). These workers provided a differential diagnosis chiefly intended to discriminate the basal Silurian members of these genera for it was stated, named differences may not reflect possible convergences during the Devonian. Indeed when considering Devonian members of Cyphaspis -focal point of the present study- the state of knowledge in the early 1990s was far from satisfactory. The majority of species known at that time came from continental Europe and Morocco, many of which had been established on poorly preserved or otherwise inadequately documented material. Subsequent records including some well-preserved complete specimens were provenant from the Ardenno-Rhenish Mountains (e.g. Basse, 1997, 2002, 2006; Basse \& Lemke, 1996; van Viersen, 2006; van Viersen \& Prescher, 2007), Morocco (Chatterton et al., 2006; van Viersen \& Prescher, 2014), Algeria (Khaldi et al., 2016), North America (Adrain \& Kloc, 1997) and Australia (Ebach, 2002), among others. The morphological variety is compelling and along with the descriptions of new species arose the challenges of their classification. Van Viersen \& Prescher (2007) emended the generic diagnosis of Adrain \& Chatterton (1996) to include Emsian to Eifelian species that were considered to be convergent on Otarion whereas van Viersen \& Prescher (2014) extended their earlier concept by adding a group of late Eifelian to Early Givetian "devil horned" species with distinctive features of putative paedomorphic origin. These corrective acts probably entail a risk of preserving Cyphapsis as a phenetically coherent group rather than that they truly contribute to the understanding of otarionine evolution.

A new study on Cyphaspis is being undertaken by us, starting with the present note. This part is chiefly concerned with the descriptions of some of the specimens from the Moroccan Devonian collected and prepared by $\mathrm{DH}$ over the past 30 years. In an attempt to bring structure to the morphological disorder we have clustered selected species into provisional groups. We underline the artificial nature of these groups in that they are based on overall similarities between large amounts of species. It follows that the establishment of formal taxa above species level has been refrained from at this stage in the process. A cladistic analysis aiming to test the monophyly of the genus will be published at a later time (AV, work in progress).

\section{Localities}

\subsection{Morocco}

Jbel Gara el Zguilma locality of Chatterton et al. (2006) (disambiguated Zguilma), SSE from our Foum Zguid locality (Fig. 1, point 5); Timrhanrhart Formation. Chatterton et al. (2006) described three trilobite-bearing levels: ZGEE1, ZGEE2 (upper Emsian), two horizons in close proximity of one another near the base of the Timrhanrhart Formation at their section, and ZGEE3 (lower Eifelian), a level near the top of the formation. Reference is made to that paper for more information about the Zguilma locality and its trilobite fauna which is, in many respects, similar to that of the Foum Zguid locality. Here we repeat only the occurrences and stratigraphic ranges of the Cyphaspis species that were reported by Chatterton et al. (2006): C. agayuara Chatterton et al., 2006 (ZGEE1), C. eberhardiei Chatterton et al., 2006 (ZGEE1), C. hamidi Chatterton et al., 2006 (ZGEE1, ZGEE2).

Foum Zguid locality at N $29^{\circ} 55^{\prime} 40.0^{\prime \prime}$, W $07^{\circ} 03^{\prime} 15.7^{\prime \prime}$; ZGEE1 to ZGEE3, grey limestones of the Timrhanrhart Formation (see Fig. 1, point 2). Trilobites (data for Morocco here and further below are based on field notes by DH and the late H. Prescher) from ZGEE1, ZGEE2 (upper Emsian): Acastoides zguilmensis Chatterton et al., 2006, Austerops menchikoffi (Le Maître, 1952) [= Phacops smoothops Chatterton et al., 2006, following Khaldi et al. (2016)], Cyphaspis eberhardiei, Diademaproetus praecursor Alberti, 1969, Erbenochile erbeni (Alberti, 1981), Gandlops tamnrherta (Chatterton et al., 2006), Gerastos marocensis Chatterton et al., 2006 [herein regarded as a distinct species instead of a subspecies for reasons discussed by van Viersen \& Prescher (2010) with regard to other Gerastos species], Hollardops mesocristatus (Le Maître, 1952), Koneprusia dahmani Chatterton et al., 2006, Leonaspis haddanei Chatterton et al., 2006, Leonaspis spinicurva Chatterton et al., 2006, Morocops granulops (Chatterton et al., 2006) [the type series of Phacops (Phacops) sparsinodosus struvei Schraut, 2000 (type species of Morocops Basse, 2006) from the Timrhanrhart Formation at Foum Zguid encompass at least two distinct phacopid species; the holotype (Schraut, 2000, fig. 8g-i; Basse, 2006, pl. 29, figs 277-279) and one paratype (ibid., fig. 8p, q) of $P$. (P.) 


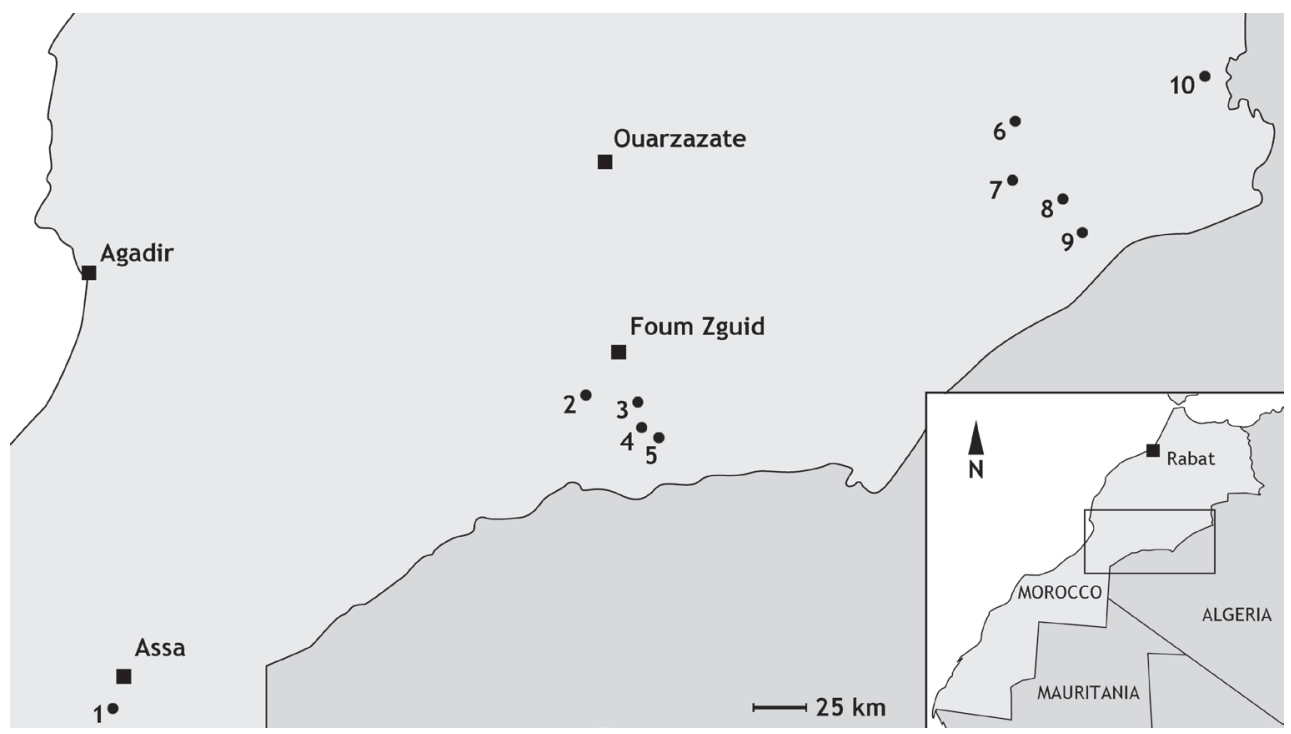

Figure 1. Simplified map of the studied area in Morocco. Localities are Tadachacht (1), Foum Zguid (2), Mdâour el Kbîr (3), Khraid (4), Zguilma (5), Issoumour / Boudib (6), Oufatène (7), Maharch (8), Zireg (9) and Talawarite (10).

sparsinodosus struvei are congeneric with species included in a new genus Barrandeops by McKellar \& Chatterton (2009); Barrandeops is thus a junior synonym of Morocops], Psychopyge sp., Scabriscutellum sp., Timsaloproetus sp., Tropidocoryphe amuri Chatterton et a1., 2006, Walliserops hammii Chatterton et al., 2006, Walliserops tridens Chatterton et al., 2006, Walliserops trifurcatus Morzadec, 2001, Wenndorfia calva (Chatterton et al., 2006), undescribed genera and species of Scutelluinae. Trilobites from ZGEE3 (lower Eifelian): Austerops menchikoffi, Cyphaspis foumzguidensis sp. nov., Cyphaspis cf. eberhardiei (herein), Diademaproetus mohamedi Chatterton et al., 2006, Gerastos sp., Hollardops aithassainorum Chatterton et al., 2006, Leonaspis haddanei, Morocops sp., Timsaloproetus dibbanus Gibb \& Chatterton, 2007, Timsaloproetus elguerrouji Gibb $\&$ Chatterton, 2007, Tropidocoryphe sp., undescribed genera and species of Scutelluinae.

Zireg locality at N 30 36' 42.2', W 04'32' 21.7', Jbel Zireg; $15 \mathrm{~m}$ above the "Ceratarges couche" (cf. van Viersen \& Prescher, 2011), ?Taboumakhloûf Formation, Eifelian (Fig. 1, point 9). Trilobites include Chamaeleoaspis sp., Cornuproetus sp., Cyphaspis bluhmi sp. nov., Gerastos sp., Phacops (sensu Basse, 2006) sp., Radiaspis sp., Thysanopeltis $\mathrm{sp}$.

Tadachacht locality, $12.5 \mathrm{~km}$ south of the village centre of Assa, western Draa Valley; marly limestones in the upper part of the Hollardops Limestone (Unit D of Becker et al., 2004), base of the Khebchia Formation, basalmost upper Emsian (Fig. 1, point 1). Trilobites identified are: Cyphaspis lerougei sp. nov., Cyphaspis tadachachtensis sp. nov., Diademaproetus praecursor, Gerastos cf. marocensis, Hollardops burtandmimiorum (Lieberman \& Kloc, 1997), Hollardops cf. mesocristatus, Koneprusia sp., Leonaspis haddanei, Scabriscutellum sp., Timsaloproetus sp., Tropidocoryphe spp., Phacopinae.

Talawarite locality at N $31^{\circ} 16^{\prime} 28.5^{\prime \prime}$, W $03^{\circ} 53^{\prime} 29.4$ "; interval between the "Gerastos and Hollardops couches" (see Gibb \& Chatterton, 2010, pp. 10, 12, 14, fig. 13) in the Amerboh Group (Fig. 1, point 10). According to Gibb \& Chatterton $(2010$, p. 12) this interval is comparable to the lower trilobite levels of the Timrhanrhart Formation at Zguilma (ZGEE1 and ZGEE2) and thus belongs to the upper Emsian. The following trilobites were identified: Cyphaspis agayuara (herein), Cyphaspis juergenhollandi sp. nov., Diademaproetus praecursor, Gerastos marocensis, Harpes sp., Hollardops mesocristatus, Koneprusia sp., Leonaspis haddanei, Morocops forteyi (McKellar \& Chatterton, 2009), Psychopyge sp., Timsaloproetus sp., Tropidocoryphe sp.

Boudib locality at N $31^{\circ} 05^{\prime} 16.6$ ', W $04^{\circ} 52$ ' 32.2”' (Gibb \& Chatterton, 2010, p. 7); calcareous mudstones of the "Thysanopeltis/Harpes couche", El Otfal Formation, Eifelian
(Fig. 1, point 6). Trilobites: Cornuproetus sp., Cyphaspis smeenki sp. nov., Cyphaspis spp., Gerastos aintawilus Gibb \& Chatterton, 2010, Harpes sp., Hollardops sp., Leonaspis sp., Phacops (sensu Basse, 2006) sp., Phaetonellus sp., Tropidocoryphe sp.

Oufatène locality, Jbel Oufatène (see Klug et al., 2014, p. 136, fig. 1); $15 \mathrm{~m}$ above "Diademaproetus couche", Eifelian (Fig. 1, point 7). Trilobite fauna: Cyphaspis eximia sp. nov., undescribed genera and species of Scutelluinae.

Maharch locality East of Ma'der el Kebir (= Section 2 of Johnson \& Fortey, 2012), "Proetid couche", Ihandar Formation, Pragian (Fig. 1, point 8). Trilobites: Belenopyge sp., Ceratonurus sp., Crotalocephalina sp., Cyphaspis maharchensis sp. nov., Dicranurus sp., Harpes sp., Koneprusia sp., Kosovopeltis sp., Leonaspis sp., Lepidoproetus sp. Metacanthina sp., Paralejurus sp., Platyscutellum sp., Pseudocryphaeus sp., Reedops sp., Tropidocoryphe sp. Reference is made to Johnson \& Fortey (2012) for further details on this locality.

Mdâour el Kbîr locality at N 29० 53' 29.6”, W $06^{\circ} 47^{\prime}$ 43.1"; marly limestones of the Assa Formation, Pragian (Fig. 1, point 3). Trilobites: Belenopyge sp., Boeckops sp., Calymene sp., Ceratonurus sp., Crotalocephalus sp., Cyphaspis heisingi sp. nov., Leonaspis spp., Odontochile sp., Paralejurus brongniarti cf. menanensis of Schraut \& Feist (2004), Reedops sp., Tropidocoryphe sp., undetermined genera and species of Scutelluinae.

Issoumour 1 locality at N $31^{\circ} 05^{\prime} 27.6^{\prime \prime}, \mathrm{W} 04^{\circ} 52^{\prime} 36.7^{\prime \prime}$, Jbel Issoumour; Tazoulait Formation, upper Emsian (Fig. 1, point 6). The holotype of Cyphaspis kippingi sp. nov. was collected from just under the "Psychopyge couche".

Issoumour2 locality at $\mathrm{N} 31^{\circ} 01^{\prime} 53.7^{\prime \prime}, \mathrm{W} \quad 05^{\circ} 02^{\prime}$ 02.3" (Gibb \& Chatterton, 2010, p. 7), Jbel Issoumour; lower "Radiaspis couche", Bou Dîb Formation, Givetian according to Gibb \& Chatterton (2010) (Fig. 1, point 6). Trilobites: Cyphaspides sp., Cyphaspis ihmadii sp. nov., Gerastos emmetus Gibb \& Chatterton, 2010.

Khraid locality at N $29^{\circ} 46^{\prime} 47.0^{\prime \prime}$, W $06^{\circ} 47^{\prime} 05.1$ ', Jbel Khraid; limestones in the lower part of the Timrhanrhart Formation (Fig. 1, point 4). The age is comparable to ZGEE2 (upper Emsian). Only the holotype of Cyphaspis khraidensis sp. nov. is described at present. A second species similar to C. hamidi occurs at this locality which has a well-developed occipital spine (van Viersen \& Prescher, 2007, p. 160).

\subsection{Other countries}

Trilobitenfelder locality near the villages of Gees and Gerolstein, Eifel, Germany; Gees Subformation of the Ahrdorf Formation, middle Eifelian. Here we record topotypical specimens including the neotype of the type 
species of Cyphaspis, C. ceratophthalmus (Goldfuss, 1843). Other Cyphaspis species which occur at the Trilobitenfelder are C. balanops (Erben, 1953), C. ranuncula (Erben, 1953) and $C$. hoepfneri (Kowalski, 1990). The reader is referred to Basse (2003) and van Viersen et al. (2009), and papers cited therein, for more details about this locality and its richly diversified trilobite fauna.

Resteigne (Loc002) locality, Ardennes, Belgium; lower part of the Hanonet Formation, uppermost Eifelian. Trilobites: Astycoryphe jorusi van Viersen \& Prescher, 2010, Cornuproetus cf. latentissimus van Viersen \& Prescher, 2010, Cyphaspis boninoi sp. nov., Cyphaspis cf. heissae of van Viersen \& Prescher (2014), Dohmiella tenuiornata van Viersen \& Prescher, 2008, Gerastos lessensis van Viersen \& Prescher, 2008, Goldius goolaertsi (van Viersen, 2007), Nyterops hollandi van Viersen, 2007, Radiaspis sp. Reference is made to Coen-Aubert et al. (1986) for further details on the Resteigne quarry.

Jemelle (Loc004) locality, Ardennes, Belgium; Chavées Member of the Jemelle Formation, middle Eifelian. Most trilobites were found as decalcified internal and external moulds although many of these are articulated complete specimens. The trilobite fauna encompasses more than 20 species (Phacopinae, Asteropyginae, Proetinae, Cornuproetinae, Tropidocoryphinae, Scutelluinae, Trochurinae, Odontopleurinae, Koneprusiinae, Otarioninae) and is comparable to the Trilobitenfelder in composition and age (van Viersen et al., 2009). We record Cyphaspis $\mathrm{sp}$. $\mathrm{J}$ here but this taxon cannot be assigned to any of our Cyphaspis groups with certainty. Van Viersen \& Prescher (2007) recorded Cyphaspis sp. B and Cyphaspis? sp. C from this locality; these are here transferred respectively to the ceratophthalmus and hamidi groups. Reference is made to van Viersen \& Prescher (2008) for a comprehensive list of trilobite species occurring in Jemelle.

Tuzla locality of Haas (1968), Bithynia, Turkey; Gebze Formation (not equal to the Gebze Member of the Istinye Formation in the Istanbul area). The trilobites from the Tuzla locality were described in detail by Haas (1968). We provide new photographs of the holotype of Cyphaspis goerlichi (Haas, 1968) from several angles since the original publication only contained a comparatively small photograph in dorsal view. Haas assigned the Gebze Formation to the Eifelian because of similarities between the odontopleurids Kettneraspis leucothea (Haas, 1968) from Turkey and Kettneraspis elliptica (Burmeister, 1843) from Germany (Ahrdorf Formation at the Trilobitenfelder locality). A close affinity of these taxa is, however, not apparent from a cladistic analysis performed by Ramsköld \& Chatterton (1991). Haas regarded the occurrence of the ammonoid Gyroceratites gracilis (Bronn, 1837) in the Gebze Formation as additional evidence in support of an Eifelian age. Jansen et al. (2007) underlined the Emsian age of $G$. gracilis while referring to Bultynck \& Hollard (1980) for its occurrence in the Khebchia Formation (early upper Emsian) in Morocco. This last unit is also the origin of C. lerougei, a species which is very similar to C. goerlichi. A late Emsian age for the Gebze Formation is furthermore inferred from the distinct turnover of the trilobite fauna (Haas, 1968, p. 192, tab. 3) which has been linked to the early late Emsian Daleje Event (see discussion under hamidi group below). Later, Haas (1982, p. 146, fig. 2) changed his opinion on the Gebze Formation and regarded it as upper Emsian. We are in agreement with this revised assignment.

\section{Material and methods}

The material is housed by the Institut royal des Sciences naturelles de Belgique (IRSNB) with the exception of one specimen in the Haas collection of the Steinmann Institute, Paleontology, Bonn (STIPB) and another specimen in the Felder collection of the Natuurhistorisch Museum Maastricht (NHMM).
Inflation of the cephalon and its individual parts appears to be both distinctive and stable among Cyphaspis species. The degree of inflation determines the inclination of the preglabellar and librigenal fields and more importantly, the shape of the median glabellar lobe and whether or not this overhangs anteriorly. These features are easily altered by tectonic deformation as commonly seen, e.g., in decalcified material from the Armorican Massif (Morzadec, 1983), Cantabrian Mountains (Smeenk, 1983) and ArdennoRhenish Mountains (Basse, 1997; van Viersen, 2006; also see Fig. 2). The types of some Cyphaspis species in the literature are so poorly preserved or otherwise inadequately documented that their validity could be challenged (this applies particularly to certain species from Bohemia). Based on the limited morphological features that can be compared we are confident enough that our species descriptions will not introduce new synonyms. We have chosen to exclude these problematic species from our discussions rather than to intervene prematurely; further research may point out that their type localities are still accessible, thus allowing for the recovery of new topotypical material. We have also excluded a number of other species in the literature that could not be validated at this time or because they may not belong to any of the groups recognised at present.
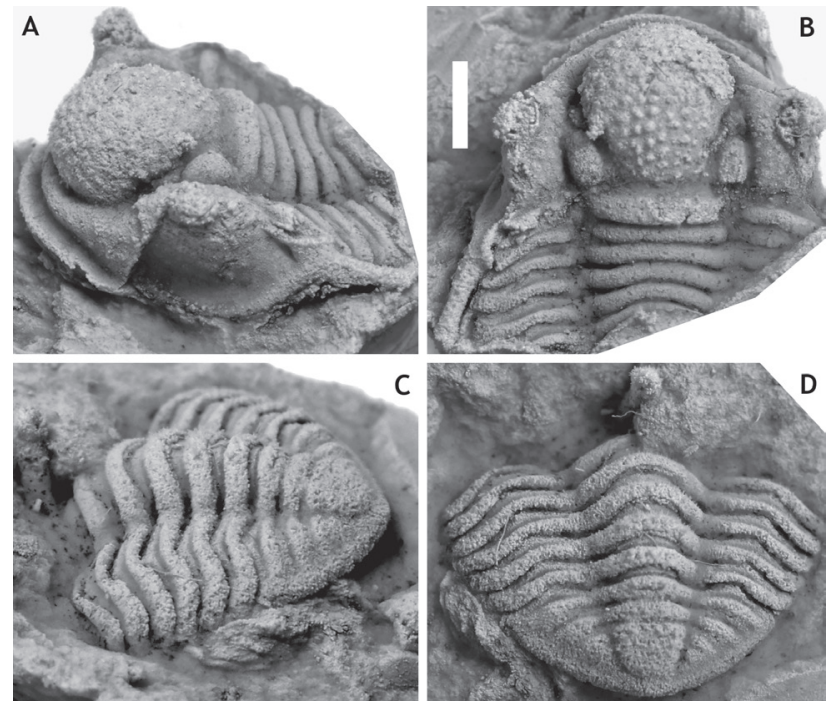

Figure 2. Cyphaspis sp. J. from the Chavées Member, Jemelle Formation at Jemelle, middle Eifelian, Belgium. Silicone cast of external mould of a complete specimen IRSNB a13022, in anterolateral (A), dorsal (B) views on cephalon, and lateral (C), dorsal (D) views on pygidium. Scale bar is $2 \mathrm{~mm}$.

Beside taphonomic conditions the cephalic features of Cyphaspis are prone to misapprehension when photographs have not been taken in strict dorsal, lateral and anterior views. Adrain \& Chatterton (1994, 1996) adopted the notion that the occipital ring is held in the dorsal plane when describing cephalic features of Otarioninae. They devised the criterion for Cyphaspis that the glabella overhangs anteriorly whereas in Otarion it does not (this concept is not followed by us for reasons already discussed by van Viersen \& Prescher, 2007). While a uniform position of the occipital ring may seem essential to maintaining consistency between descriptions of disarticulated sclerites, our articulated complete specimens have demonstrated that the cephalon is not always in its natural 'resting' position when the occipital ring is held vertically. In some cases this may even lead to wrong interpretations of the glabellar morphology as for example in C. smeenki (see below). Where we provide descriptions and photographs of cephalic features in dorsal view these are the natural resting positions if articulated specimens are concerned.

\section{Systematic palaeontology}

Family Aulacopleuridae Angelin, 1854

Subfamily Otarioninae Richter \& Richter, 1926

Tribe Otarionini Richter \& Richter, 1926 


\section{Genus Cyphaspis Burmeister, 1843}

Type species. Phacops ceratophthalmus Goldfuss, 1843, by designation under the plenary powers (ICZN Opinion 1434).

Diagnosis. Van Viersen \& Prescher (2014) provided a revised generic diagnosis. This is sustained for the time being, with the sole addition that the sixth thoracic axial ring may be completely devoid of a central tubercle or spine.

Discussion. Members of each of the Cyphaspis groups designated below are similar enough to one another to restrict the species descriptions to diagnostic and otherwise distinctive characters. Adrain \& Chatterton (1994, 1996) reviewed a number of conspicuous morphological features of the Otarionini. We discuss here several characters visible on large holaspid specimens of Devonian putative Cyphaspis species which may be of significance to future analyses:

1. Palpebral pit: all species bear a small pit on the palpebral lobe. Its location seems to be the same as that of P1, a hollow spine typical of meraspid members of the Otarionini with which the palpebral pit is possibly homologous. The pits can also be found in Silurian members of Cyphaspis and Otarion (e.g. Otarion huddyi Adrain \& Chatterton, 1994; see ibid., fig. 5.3) but there they are positioned more abaxially, closer to the visual surface. This feature is not restricted to Proetida as it is widely shared, e.g., with members of Odontopleurida and Phacopida.

2. Fixigenal tubercles: most species bear a tubercle on the fixigena lateral of the anterior margin of the visual surface (e.g. C. tadachachtensis; see Fig. 26F). If present, the tubercles are always visible on both fixigenae and share their location with fixigenal spines Fx4 in meraspids of the Otarionini. Another tubercle lateral of L1 in the holotype of C. lerougei may correspond to Fx1.

3. Posterior tegimen: many species have a densely granulose area that covers a large part of the pygidium and continues onto the lateral extremities of the thoracic pleurae. This area is often demarcated anteriorly by larger, rounded (e.g. C. heisingi; see Fig. 21E) to thimble-shaped (e.g. Cyphaspis belgica van Viersen \& Prescher, 2007; see ibid., pl. 2, fig. 1c) tubercles and a sudden (ventral) change of inclination of the covered parts of the pleurae. We term this feature posterior tegimen (Lat.: body armor, cover).

4. Subocular patches: first described by Basse (1997, pp. $118,119)$ in specimens of $C$. ceratophthalmus; many species have a small patch anterior of the eye which is of various shapes, devoid of prosopon, and slightly inflated or not elevated at all. The feature is also present on internal moulds (see Basse, 1997, pl. 10, fig. 13a). A posterior subocular patch can be present as well (e.g. C. eximia; see Fig. 6G) although perhaps not always as clearly. Subocular patches can also be recognised in other proetides, as for example in species of Diademaproetus.

5. Thoracic dorsal spine: a long posteriorly directed spine centrally on the sixth thoracic axial ring is characteristic of most species. In these cases the axial ring has grown significantly beyond the size of the adjacent rings. Other species can have a rudimentary spine (e.g. C. kippingi; see Fig. 14C), a tubercle (e.g. C. foumzguidensis; see Fig. 16B) or no median structure at all (e.g. C. ranuncula; see Fig. 9); in these cases the sixth thoracic axial ring is marginally longer (sag., exsag.), if different at all from the adjacent rings. Secondary loss of the dorsal spine is particularly widespread in members of the hamidi group. Reversals (i.e., the development of a dorsal spine in species that evolved from a spineless ancestor) are assumed to have occurred but were not positively identified by us.

\section{Cyphaspis ceratophthalmus group}

Assigned taxa. Otarion (Otarion) balanops Erben, 1953, Eifelian, Germany; Cyphaspis bluhmi sp. nov.,
Eifelian, Morocco; Cyphaspis boninoi sp. nov., Eifelian, Belgium; Phacops ceratophthalmus, Eifelian, Germany; Cyphaspis eximia sp. nov., Eifelian, Morocco. Additional taxa: Cyphaspis cf. ceratophthalma and Cyphaspis sp. n. 44 aff. ceratophthalma of Basse (1997), Eifelian, Germany; Cyphaspis sp. B of van Viersen \& Prescher (2007), Eifelian, Belgium.

Discussion. Members of the ceratophthalmus group occur in middle to upper Eifelian strata in the Ardenno-Rhenish Mountains and probably coeval sections in Morocco. All have a strongly inflated to somewhat cone-shaped, anteriorly overhanging median glabellar lobe; interocular fixigena is strongly inflated (tr.) and librigenal field is very steep to vertical (tr.), these last two features together forming a robust pillar to support the (usually) tall eye; moderately to very long, thin, proximally upward curved genal spines; weak ornament on cephalon and thorax. Distinctive of at least three members (C. ceratophthalmus, C. eximia and $C$. boninoi) is the retention of G2 and G3 crowded anteriorly on the median glabellar lobe in large holaspides. This feature has been demonstrated to vary intraspecifically in $C$. belgica (see van Viersen \& Prescher, 2007), a member of the hamidi group; thus it is neither exclusive to, nor diagnostic of, the ceratophthalmus group. Cyphaspis ceratophthalmus has two granules on the posterior cranidial border and serially homologous ones on each thoracic posterior pleural band; $C$. eximia and C. bluhmi also seem to have these granules as far as preservation allows their detection. All members except the type species and an undescribed species from Morocco show a fairly stable inclination of the glabella (lateral view) between $\mathrm{S} 0$ and the dorsoventrally highest point, which is anterior of the eyes.

\section{Cyphaspis ceratophthalmus (Goldfuss, 1843)}

(Figs 3-5)

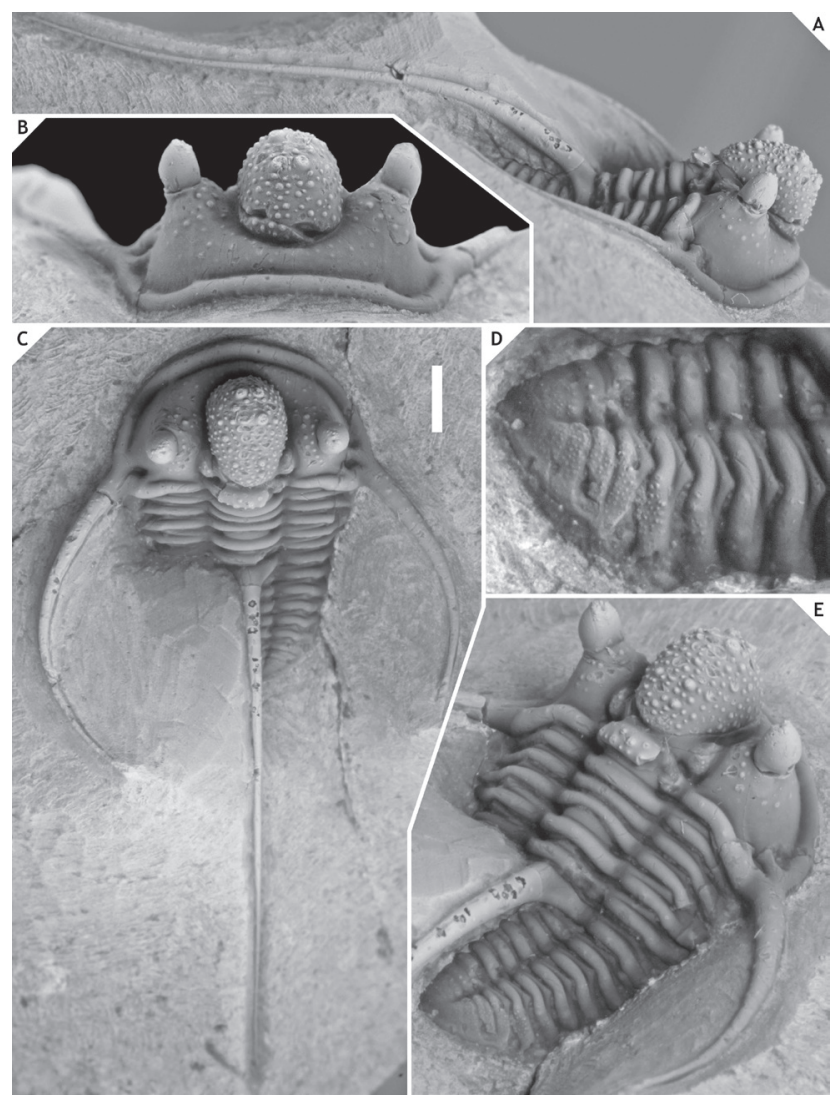

Figure 3. Cyphaspis ceratophthalmus (Goldfuss, 1843) from the Gees Subformation, Ahrdorf Formation at the Trilobitenfelder, middle Eifelian, Germany. Complete specimen (proposed neotype) IRSNB a13017, in lateral (A), anterior (B), oblique dorsal (C), close-up of pygidium (D), oblique posterolateral (E) views. Scale bar is $2 \mathrm{~mm}$. 


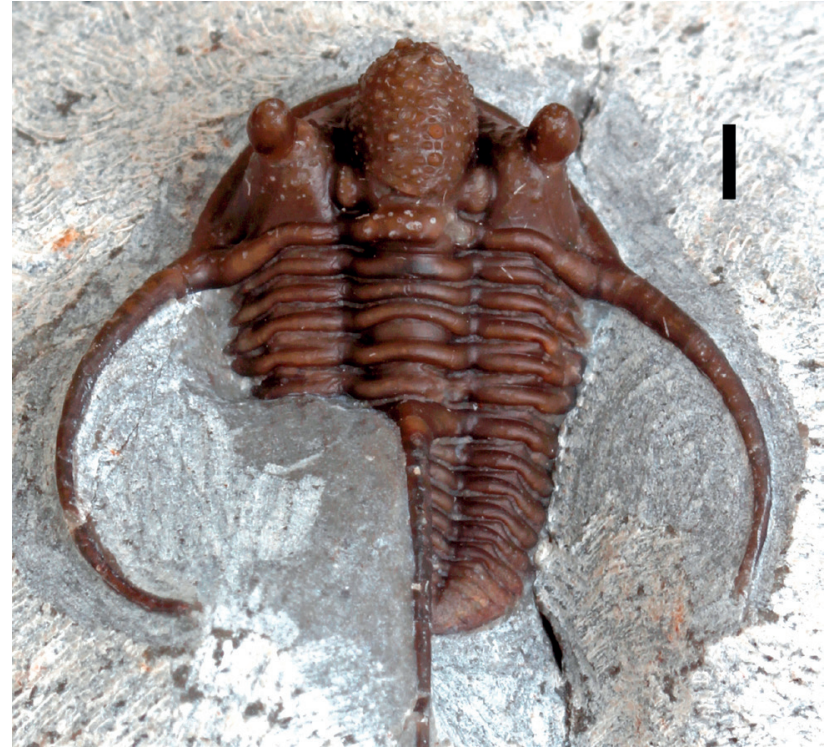

Figure 4. Cyphaspis ceratophthalmus (Goldfuss, 1843) from the Gees Subformation, Ahrdorf Formation at the Trilobitenfelder, middle Eifelian, Germany. Complete specimen (neotype) IRSNB a13017 in dorsal view. Scale bar is $2 \mathrm{~mm}$. The brownish colour is common among trilobites from this locality.

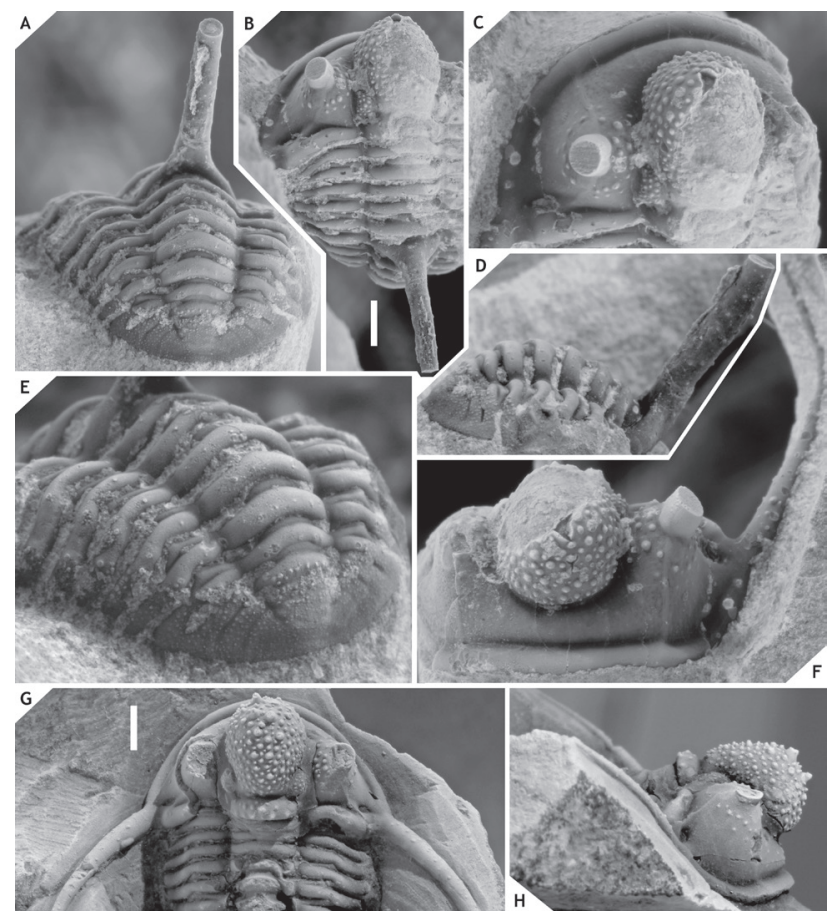

Figure 5. Cyphaspis ceratophthalmus (Goldfuss, 1843) from the Gees Subformation, Ahrdorf Formation at the Trilobitenfelder, middle Eifelian, Germany. Complete specimen IRSNB a13018, in posterior (A), dorsal (B), dorsal close-up of cephalon (C), lateral close-up of pygidium and posterior part of thorax (D), oblique posterolateral (E), anterior (F) views. Complete specimen NHMM 197954 in dorsal $(\mathrm{G})$ and lateral $(\mathrm{H})$ views (the right axial furrow of the cranidium is filled with glue). Scale bars are $2 \mathrm{~mm}$.

* 1843 Phacops ceratophthalmus Goldfuss, pp. 564, 565, pl. 5 , fig. 2 .

Holotype. The holotype is presumed lost; to replace this, a complete specimen (IRSNB a13017; see Figs 3,4) is here designated neotype.

Type locality and horizon. In all probability Trilobitenfelder locality, Germany; "Gees trilobite beds" (sensu van Viersen et al., 2009), Gees Subformation, Ahrdorf Formation, middle Eifelian.
Other material. Two topotypical complete specimens (IRSNB a13018, NHMM 197954).

Discussion. Articulated specimens of C. ceratophthalmus are known to have been quite common at the Trilobitenfelder locality before its closure in the 1980s (pers. comm. with J. Savelsberg and the late H. Prescher in 2009) yet surprisingly few photographs of whitened specimens have been published (cf. Thomas \& Owens, 1978, pl. 7, figs 4, 8; Basse, 1997, pl. 10, fig. 13; Basse, 2002, pl. 30, figs 604-608). The morphology of this species was briefly described by Richter (1909) and Basse (1997); those accounts generally are to the point except that Richter reported 12 thoracic segments. We agree with Basse (1997) that this must have been a typographical error in view of the fact that we have never counted more than 11 segments (however, see discussion under hamidi group below).

There is ample morphological disparity among the $>100$ topotypical complete specimens that we have seen (mainly invest. of priv. coll.); this has yet to be fully appreciated. As a preliminary note we wish to mention the variable thickness and initial direction of the thoracic dorsal spine; a large median tubercle may be developed on the occipital ring or may be absent altogether; median glabellar lobe is distinctly cone-shaped and anteriorly overhanging or comparatively weakly vaulted and smoothly rounded (sagittal section); ornament on median glabellar lobe varies from granules alternating with tubercles adaxially, to exclusively tubercles; G2 and G3 can be very small (similar to other tubercles in this area), developed as long cones, or as thick, short, yet very thick cones (section of a cone can equal sagittal length of occipital ring); G2 can be much larger than G3; G2 or G3 tubercles are occasionally misaligned (i.e., one tubercle is moved along the exsagittal line, just posterior or anterior of the other tubercle in the same pair); eye and L1 sizes vary substantially; ornament on preglabellar and librigenal fields ranges from all over to concentrated around the eye. These variations also have a bearing on C. balanops which was originally described from the same locality and horizon. Erben (1953) established this species on comparatively poorly preserved cephalic remains only some of which are actually strato- and topotypical (see Basse, 2002, p. 74). Regardless of the specific affiliations of the paratypes, the morphology of the holotype of $C$. balanops appears to fall within the boundaries of $C$. ceratophthalmus as alluded to above. This raises the question of whether $C$. balanops should continue to be recognised as a distinct species, or not. A reassessment of $C$. ceratophthalmus is long overdue but has been complicated for two reasons:

1. Most trilobites were collected at the type locality with limited stratigraphic control, or none at all, and a description of the successions has never been published. Van Viersen et al. (2009) defined the so-called "Gees trilobite beds" based on bentonite horizons but added that details on lithology of the section and the accompanying macrofauna would be published at a later date.

2. The morphology of the holotype is known exclusively from circumstantial evidence. Goldfuss (1843, pl. 5, fig. 2) illustrated a single complete specimen which he obviously intended as the holotype but his drawings were idealised and barely resemble specimens assigned to $C$. ceratophthalmus at present. To our knowledge, photographs of Goldfuss' specimen have never been published. Its whereabouts remain unknown despite efforts by us and other workers to trace it (pers. comm. with M. Basse, G. Heumann and B. Schoenemann in 2015, and the late H. Prescher in 2013). Hahn, in response to a proposal by Thomas \& Owens (1980) to the ICZN to designate Phacops ceratophthalmus as the type species of Cyphaspis, made enquiries as to the status of the type specimen and the possible need for a neotype. Thomas \& Owens replied that they were unable to trace the type but that the identity of the species had never been in doubt (ICZN, 1987). However, we believe that the variation 
among putative specimens of $C$. ceratophthalmus from the type locality, along with the ambiguous relation to $C$. balanops, call for a reconsideration of this last statement. The only tangible connection between the holotype and specimens assigned to $C$. ceratophthalmus at present is inferred from Goldfuss' (1843, pp. 564, 565) description in which he mentioned several larger tubercles on the front of the glabella and a conspicuous rounded pit near the genal corner. The combination of these features is a fairly unique one and known to us exclusively in some of the members assigned to the ceratophthalmus group herein. Thus we must assume that Goldfuss' holotype belongs to one of the various morphotypes that occur at the Trilobitenfelder.

In order to salvage the name $C$. ceratophthalmus we here designate IRSNB a13017, a representative of the commonest morphotype at Gees, neotype. The arbitrary assignments of other morphotypes to C. ceratophthalmus as well as the independent rank of $C$. balanops are retained, at least for the time being.

\section{Cyphaspis eximia sp. nov.}

(Fig. 6)

Etymology. Derived from eximius (Lat.: distinguished), in reference to its distinctive cephalic morphology with spiny $\mathrm{G} 2$ and $\mathrm{G} 3$.

\section{Holotype. IRSNB a13010, complete specimen.}

Type locality and horizon. Oufatène locality, Morocco; 15 $\mathrm{m}$ above the "Diademaproetus couche", Eifelian.
Diagnosis. Cephalon is exceedingly strongly vaulted (sag., tr.) for a member of the group; steep librigenal field lateral of the eye and high median glabellar lobe of parabolic outline (lateral view); G2 and G3 are short, stout spines; closely spaced tubercles on fixigena and librigena concentrated around the eye; preglabellar field is distinctly more vaulted (sag.) medially than laterally, as if anteriorly deflected by the glabella; long, gently curved dorsal and genal spines.

Description. Low occipital ring with granules along its posterior margin; median glabellar lobe of ovoid outline, widest (tr.) and dorsoventrally highest just anterior of the eyes, quickly ascending between S0 and middle of L1, then decreasingly gaining height until reaching its highest point, overhanging anteriorly $\left(>90^{\circ}\right)$, bearing an alternation of tubercles and granules except around G2 and G3; L1 is small, weakly defined laterally, bearing a few granules; small tubercles are concentrated around the eye and several more scattered on the preglabellar and librigenal fields; anterior and posterior subocular patches are well demarcated through the absence of tubercles; anterior and lateral cephalic borders bear closely spaced granules; surface of posterior border is smooth.

Thorax consists of 11 segments with a long dorsal spine on the sixth axial ring; dorsal surface of thorax is devoid of prosopon, a few fine granules excepted; dorsal spine bears randomly scattered granules.

Pygidium with four axial rings; four pairs of pleurae separated by straight furrows that are distinct until the pygidial border (the left anterior interpleural furrow reaches the pygidial margin in the holotype; this is an artefact);
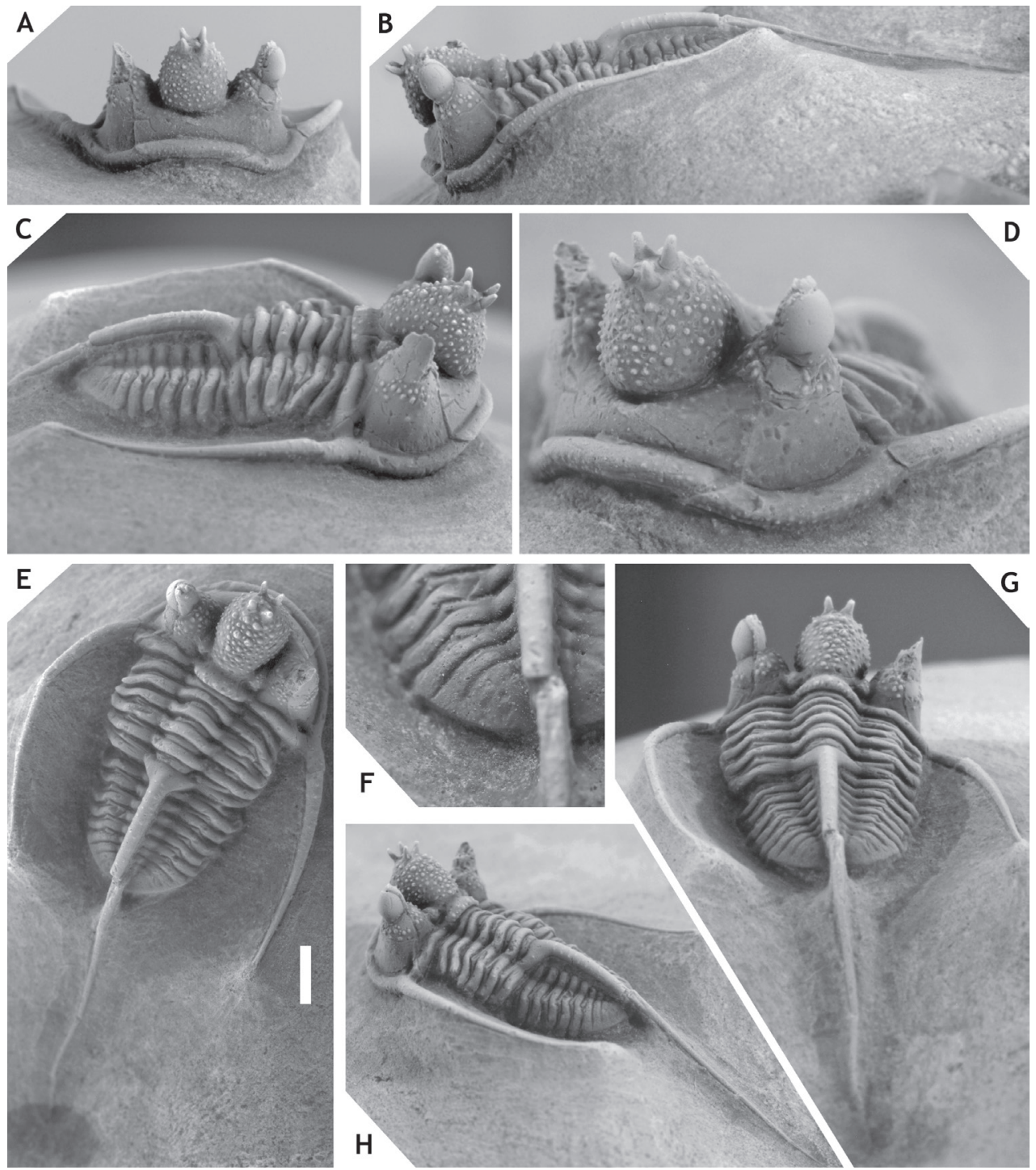

Figure 6. Cyphaspis eximia sp. nov. from $15 \mathrm{~m}$ above the "Diademaproetus couche" at Oufatène, Eifelian, Morocco. Holotype complete specimen IRSNB a13010, in anterior (A), lateral (B), oblique lateral (C), anterolateral (D), dorsal (E), close-up of pygidium (F), posterolateral $(\mathrm{H})$, posterior (G) views. Scale bar is $2 \mathrm{~mm}$. 


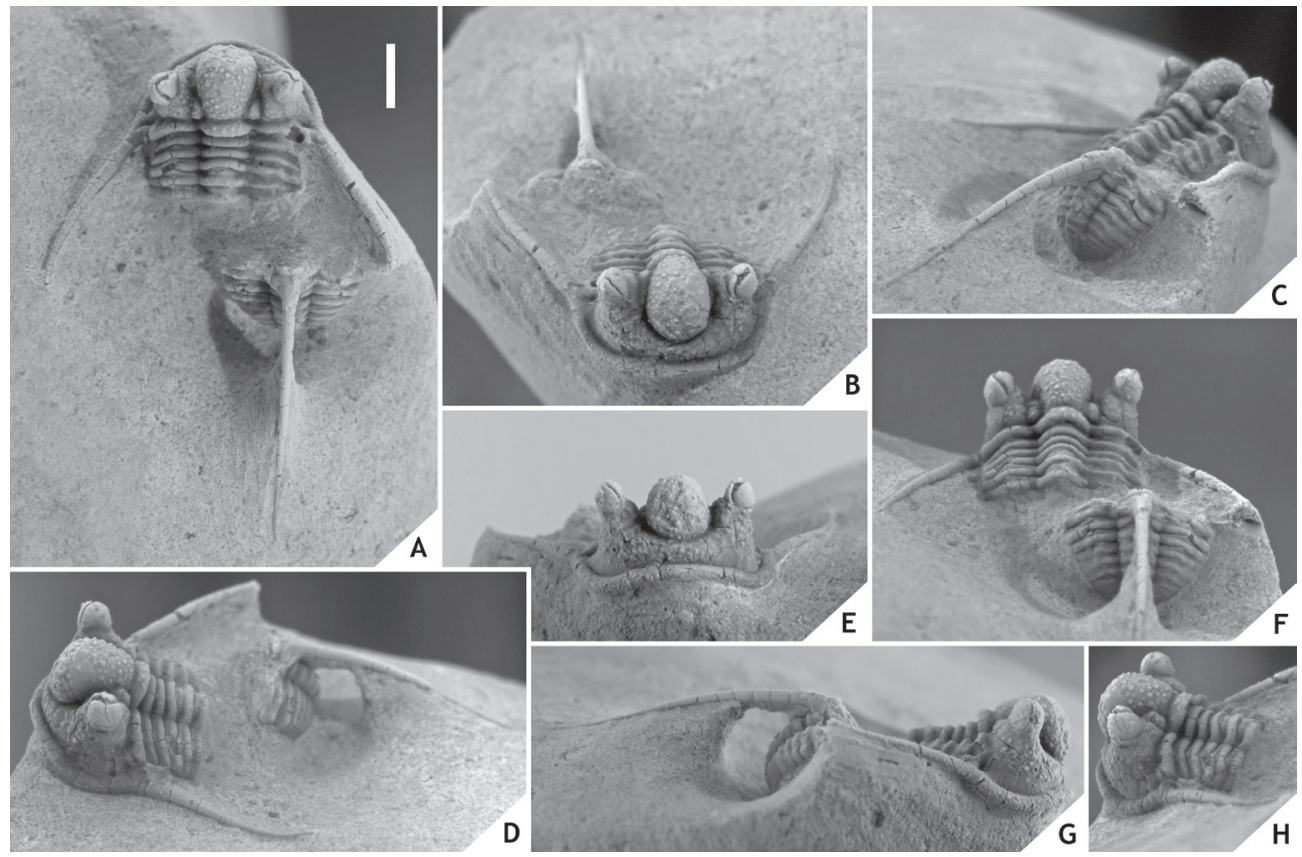

Figure 7. Cyphaspis bluhmi sp. nov. from $15 \mathrm{~m}$ above the "Ceratarges couche", ?Taboumakhloûf Formation, at Zireg, Eifelian, Morocco. Holotype complete specimen IRSNB a13003, in dorsal (A), oblique anterior (B), right posterolateral (C), oblique left lateral (D), anterior (E), posterior $(\mathrm{F})$, right lateral $(\mathrm{G})$, left posterolateral $(\mathrm{H})$ views. Scale bar is $2 \mathrm{~mm}$.

pleural furrows are only visibly developed on the first pleural segment; border furrow is only developed as a slight change of inclination between the pleural field and the pygidial border; border is increasingly narrow posteriorly; no prosopon is visible on the pygidium of the holotype although the surface is comparatively poorly preserved in this area.

Discussion. Cyphaspis eximia is in many ways similar to C. ceratophthalmus. Among shared features are the deep, pit-like posterior border furrow of librigena; comparatively few tubercles on the librigenal and preglabellar fields; weakly impressed pygidial axial and pleural forrws. The German species demonstrates a more smoothly rounded outline (lateral view) of the median glabellar lobe; G2 and G3 are never spiny; genal spines are proximally dorsally and distally inward curved; a generally less vaulted cephalon (sag., tr.); the anterior and lateral cephalic borders are completely devoid of prosopon. The holotype of $C$. eximia bears several pairs of enlarged tubercles on the median glabellar lobe posterior of $\mathrm{G} 2$.

\section{Cyphaspis bluhmi sp. nov.}

\section{(Fig. 7)}

\section{Etymology. Named after Rainer Bluhm.}

\section{Holotype. IRSNB a13003, complete specimen.}

Type locality and horizon. Zireg locality, Morocco; $15 \mathrm{~m}$ above the "Ceratarges couche", ?Taboumakhloûf Formation, Eifelian.

Diagnosis. Small sized member of the ceratophthalmus group with comparatively large eyes; comparatively weakly vaulted (tr.) median glabellar lobe; preglabellar field is vertical (sag., exsag.); ubiquitous cephalic ornament except abaxially on the librigenal field; posterolaterally directed, gently curved genal spines that reach backward until the posterior pygidial margin.

Description. Low occipital ring bearing randomly scattered tubercles; median glabellar lobe of ovoid outline, widest (tr.) and dorsoventrally highest just anterior of the eyes, steadily gaining height between S0 until reaching its highest point, overhanging anteriorly, bearing an alternation of smaller and larger tubercles; G2 and G3 seem to be absent; L1 is small, covered with granules; anterior and lateral cephalic borders bear closely spaced granules.
Thorax consists of 11 segments with a long, thin dorsal spine on the sixth axial ring; each posterior pleural band bears a row of several tubercles.

Pygidium with four axial rings; four pairs of pleurae separated by straight furrows that are distinct until the pygidial border; pleural furrows are not developed; border furrow is not developed; border is narrow; no prosopon is visible on the pygidium.

Discussion. Cyphaspis bluhmi and C. boninoi are possibly the stratigraphically highest members of the ceratophthalmus group. An age indication of the species from Zireg cannot be precisely established at present but the type material of $C$. boninoi was collected from just below the Eifelian-Givetian boundary by E. Bonino and A. van Rossum during field excursions with AV. Both species bear all of the characteristic features of basal members of the group while at the same time they attest to a trend of eye size increase and decreased glabellar inflation. Additionally, both species are very small. The G2 and G3 tubercles are retained in C. boninoi but they could not be confirmed in C. bluhmi (partly because of poor preservation of this area).

\section{Cyphaspis boninoi sp. nov.}

(Fig. 8)

v 2007 Otarioninae gen. \& sp. indet.; van Viersen, p. 16.

v e.p. 2007 Cyphaspis; van Viersen \& Prescher, p. 161 [only Resteigne].

v 2008 Cyphaspis sp.; van Viersen \& Prescher, p. 10.

v 2015 Cyphaspis sp.; Lebrun \& van Viersen, p. 27.

Etymology. Named after Enrico Bonino who donated the holotype for study.

Holotype. IRSNB a13019, cephalon (Fig. 8A, B, D, E).

Paratype. IRSNB a13020, pygidium.

Type locality and horizon. Resteigne locality, Belgium; lower part of Hanonet Formation, uppermost Eifelian.

Diagnosis. Member of the ceratophthalmus group with exceedingly small L1; median glabellar lobe lower than the eyes; librigenal field bearing several tubercles adjacent to the eye; broad (tr.) anterior subocular patch; eyes comparatively large for a member of the group; straight, long genal spine that retains direction of librigenal border 
Figure 8. Cyphaspis boninoi sp. nov. from the lower part of the Hanonet Formation, at Resteigne, uppermost Eifelian, Belgium. Holotype cephalon IRSNB a13019, in oblique dorsal (A), anterior (B), lateral (D), oblique anterolateral (E) views. Scale bar is $2 \mathrm{~mm}$. Paratype pygidium IRSNB a13020, in dorsal (C), latera (F) views. Scale bar is $1 \mathrm{~mm}$.
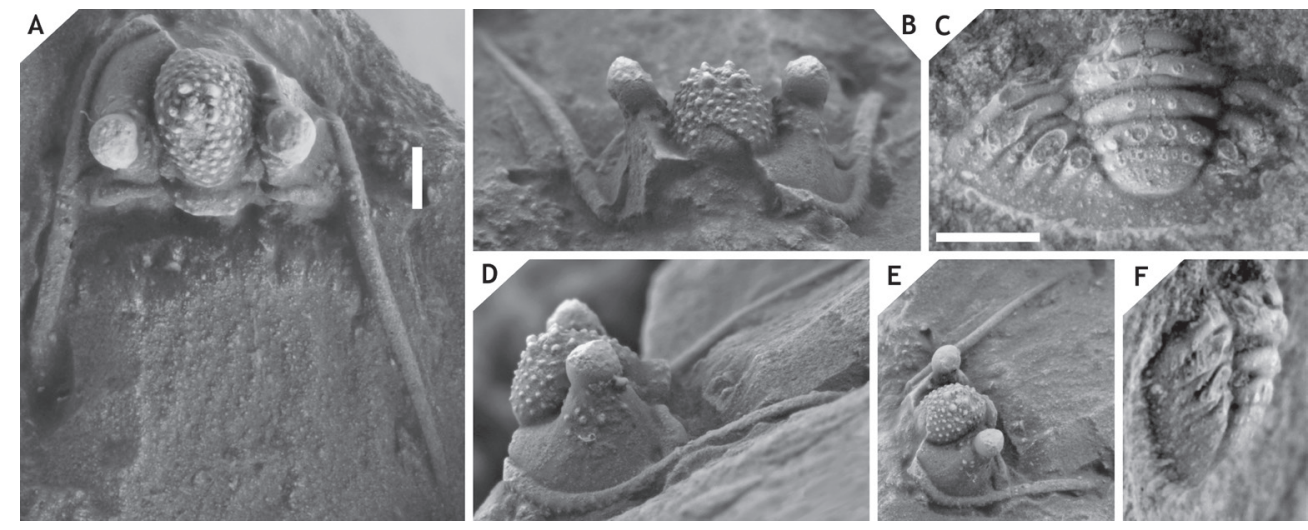

before slightly diverging; anterior two pygidial axial rings with pseudoarticulating half-ring; third axial ring has a rudimentary pseudoarticulating half-ring which is only medially developed as a small indention; interpleural and pleural furrows are firmly impressed; posterior tegimen consists of granules and is anteriorly demarcated by tubercles.

Description. Low occipital ring bearing numerous tubercles; median glabellar lobe of elongated ovoid outline, widest (tr.) and dorsoventrally highest just anterior of the eyes, steadily gaining height between S0 until reaching its highest point, overhanging anteriorly, bearing uniformly sized and spaces tubercles that are slightly smaller on frontal part; G2 and G3 are moderately large cones; granules on anterior to lateral cephalic borders are not visible dorsally.

The thorax is not known. Pygidium with four axial rings; each ring bears two tubercles pairs close to the axial furrow, each consecutive ring has an increasing amount of tubercles between these pairs; four pairs of pleurae, the posterior pleural bands of which bear a row of granules; border furrow is not developed; border widens slightly backwards; postaxial field is depressed medially.

Discussion. Cyphaspis boninoi sp. nov. is assigned to the ceratophthalmus group based on cephalic features such as the well developed G2 and G3 tubercles; highest point of glabella is anterior of the eyes; steep librigenal fields; long, dorsally directed genal spines; scant ornament on anterior to lateral cephalic borders and preglabellar and librigenal fields.

The pygidium of $C$. boninoi has four axial rings which is typical (although not exclusive) of the ceratophthalmus group. The anterior pleural bands of the paratype are damaged just interior of the change in inclination of the pygidial pleural field. This is precisely the area where exceedingly large tubercles may be found in other Cyphaspis species (exceptionally so in $C$. belgica; see van Viersen \& Prescher, 2007, pl. 2, fig. 1c) where the posterior tegimen is anteriorly developed as a tubercle row. The localised damage in the paratype pygidium leads us to speculate that it carried large tubercles here.

\section{Cyphaspis hamidi group}

Assigned taxa. Cyphaspis gaultieri Rouault, 1851, Emsian, France; Otarion (Otarion) goerlichi Haas, 1968, Emsian, Turkey; Cyphaspis hamidi Chatterton et al., 2006, Emsian, Morocco; Cyphaspis juergenhollandi sp. nov., Emsian, Morocco; Cyphaspis kippingi sp. nov., Emsian, Morocco; Cyphaspis lerougei sp. nov., Emsian, Morocco; Cyphaspis foumzguidensis sp. nov., Eifelian, Morocco; Otarion (Conoparia) hoepfneri Kowalski, 1990, Eifelian, Germany; Cyphaspis hoepfneri pumilio Basse, 1997, Eifelian, Germany; Cyphaspis monachocephalus Spriestersbach, 1919, Eifelian, Germany; Cyphaspis smeenki sp. nov., Eifelian, Morocco; Cyphaspis unguloides belgica van Viersen \& Prescher, 2007, Eifelian, Belgium; Otarion (Otarion) unguloides ranunculum Erben, 1953, Eifelian, Germany; Otarion (Otarion) unguloides unguloides Erben, 1953, Eifelian, Germany. Additional taxa: Otarion aff. druida of Smeenk (1983) (in part), Emsian, Spain; Cyphaspis ?hamidi of Khaldi et al. (2016), Emsian, Algeria; Cyphaspis cf. lerougei sp. nov., Emsian?, Morocco; Otarion (Otarion) sp. D of Alberti (1969), Emsian/Eifelian transition, Morocco; Cyphaspis cf. monachocephalus of Basse (1997), Eifelian, Germany; Cyphaspis aff. unguloides of Basse (1997), Eifelian, Germany; Cyphaspis cf. unguloides of Basse (2002), Eifelian, Germany; Cyphaspis? sp. C of van Viersen \& Prescher (2007), Eifelian, Belgium; Cyphaspis n. sp. 3 and Cyphaspis sp. 4 of Basse (2002), Eifelian, Germany; Cyphaspis sp. I (herein), Givetian?, Morocco. Tentatively assigned are Otarion (Otarion) convexum of Alberti (1968), Emsian, Germany; Otarion (Otarion) polonicum praecedens Kielan, 1954, Eifelian, Poland; Cyphaspis cf. nausicaa of Basse (2002), Givetian, Germany.

Discussion. Along with the description of C. hamidi Chatterton et al. (2006) pointed out several striking similarities to $C$. ranuncula which they believed might warrant distinct generic rank: both species are small, have comparatively small and straight genal spines, comparatively large eyes, and the spine on the sixth thoracic axial ring reduced to a tubercle (or, in the case of $C$. ranuncula, in fact absent). Van Viersen \& Prescher (2007) argued that these features are also shared with other Cyphaspis species and that they are likely to have limited bearing on generic assignments. Our hamidi group is a much extended concept of Chatterton et al. (2006) which encompasses a large array of Emsian to Eifelian taxa from (peri-)Gondwana and Laurussia, including $C$. hamidi and $C$. ranuncula. Stratigraphically low members have a weakly vaulted cephalon covered with ubiquitous, closely spaced and uniformly sized ornament; exceedingly narrow interocular fixigenae; weakly inflated median glabellar lobe (as opposed to the peramorphic, anteriorly overhanging median glabellar lobe of most other Cyphaspis species); large, spherical eyes; long (sag., exsag.), weakly inflated anterior cephalic border; long, straight and occasionally very robust genal spines; small pygidium with three axial rings and rarely a weakly defined fourth one; medially upturned posterior pygidial border; posterior tegimen consists of fine, densely spaced granules. The dorsal spine on the sixth thoracic axial ring varies between species from long to short, or absent, but the oldest species of which the thorax is known (C. lerougei) only has a tubercle here. A long occipital spine is presumably of paedomorphic origin (Adrain \& Chatterton, 1996; van Viersen \& Prescher, 2014) and only ever developed in a few undocumented species restricted to the upper Emsian in Morocco (van Viersen \& Prescher, 2007) and Germany (pers. comm. with M. Basse in 2015).

Members of the hamidi group demonstrate, typically, features that have been regarded as convergences on Otarion (cf. Chatterton et al., 2006; van Viersen \& Prescher, 2007). Adrain \& Chatterton (1994) suggested that Cyphaspis, which has 11 thorax segments, evolved from an arrested degree 11 meraspid of an ancestor in Otarion with 12 thorax segments. We report the discovery of a unique 


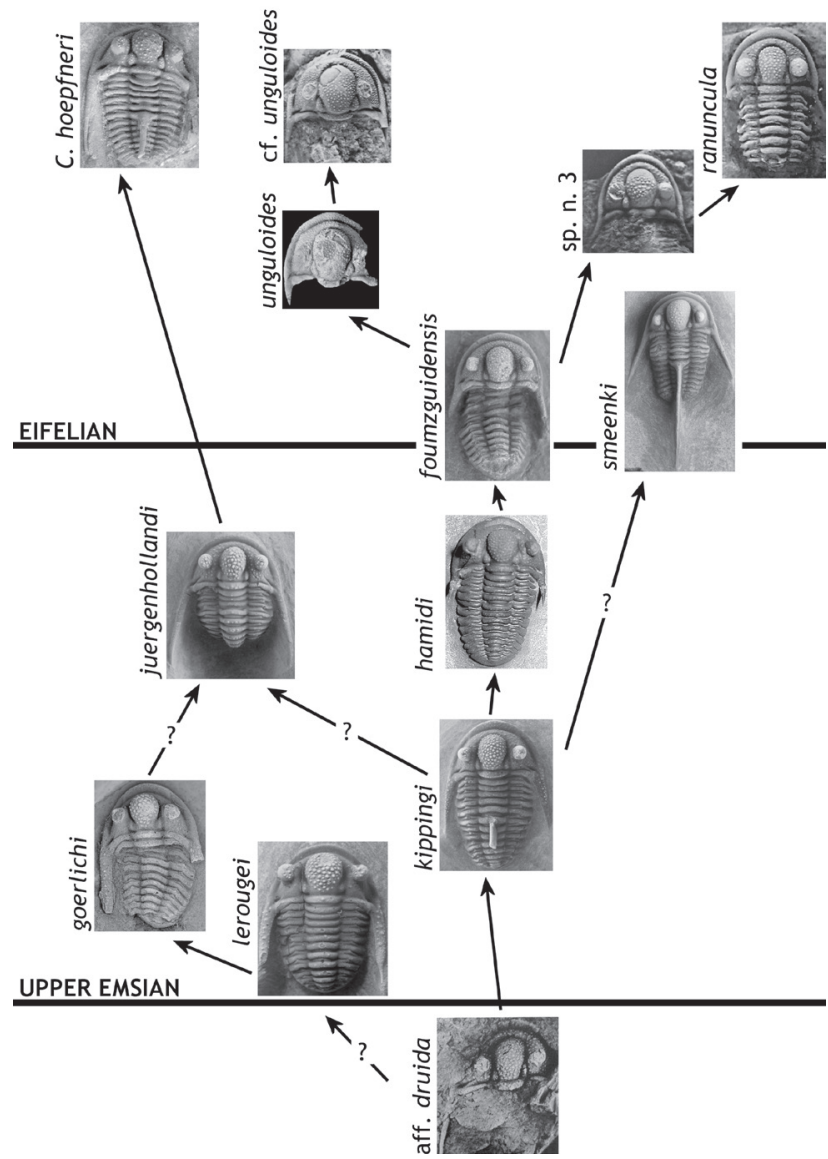

Figure 9. Hypothesised relationships between species of the hamidi group. Figures as far as they are not taken from the present note: C. aff. druida (Smeenk, 1983, pl. 21, fig. 4); C. hamidi (topo- and stratotypical; coll. DH); C. unguloides (van Viersen \& Prescher, 2007, pl. 1, fig. 2a); C. hoepfneri (van Viersen \& Prescher, 2007, pl. 2, fig. 10a); C. sp. n. 3 (Basse, 2002, pl. 29, fig. 588), C. ranuncula (holotype; Basse, 2002, pl. 29, fig. 597), C. cf. unguloides (Basse, 2002, pl. 29, fig. 591). At the time of this writing there exists an undescribed species from the middle upper Emsian in Germany which could be ancestral to Eifelian hamidi group members in the Ardenno-Rhenish Mountains (M. Basse, pers. comm. in 2015).

specimen of an undescribed hamidi group member at our Foum Zguid locality which has 12 thorax segments. This amount is striking for it has been generally assumed that post-cephalic segment number variability was constrained in phylogenetically derived trilobites subsequent to the Cambrian radiation. Hughes \& Chapman (2001), however, have demonstrated that this rule is not inviolable in certain highly derived (aulacopleurid) members of proetide clades. We assume that likewise, some Cyphaspis species may have been able to loosen constraints on thoracic segmentation and return to the plesiomorphic 12 segments. Future efforts by us will be focused on the recovery of additional specimens from the particular level at Foum Zguid.

The geographical dispersal of the oldest known hamidi group members in the Rheic Ocean typically coincided with that of various Bohemian trilobites during the late Early to early late Emsian and probably benefited from an eustatic sea level rise (T-R cycle Ib of Johnson et al., 1985) that led to the Daleje Event and its aftermath. The incursions of hamidi group members were often associated with one other, non-hamidi group Cyphaspis species. The stratigraphically lowest representative known to us is a partial cephalon of "Otarion aff. druida" recorded by Smeenk (1983, pl. 21, fig. 4) along with other trilobites of Bohemian type, basally in the Requejada Member of the Abadía Formation in Spain. According to García-López et al. (2002) the Requejada Member ranges from the upper excavatus into the nothoperbonus Conodont zones (upper lower Emsian). The Daleje Event is correlated with the marly Vañes Beds that make up the summit of this unit (García-Alcalde, 1997). Cyphaspis lerougei is the oldest member from Morocco known to date. It occurs in the Hollardops Limestone (basalmost upper Emsian) at Tadachacht, just below the main deepening of the Daleje Event (Unit E of Becker et al., 2004). The exceedingly similar C. goerlichi was recorded by Haas (1968) from the Gebze Formation in Turkey who made note of a drastic turnover of the trilobite fauna between the Gebze and lowerlying Dede formations. The onset of Bohemian elements in Turkey during this interval has been linked to the Daleje Event (Chlupáč \& Kukal, 1986). Another early representative of the hamidi group, $C$. gaultieri, was recorded by Morzadec $(1981,1983)$ from the Marrettes and Le Fret Formations in the Armorican Massif. Vidal et al. (2011), referring to Plusquellec (2007), positioned the Daleje Event at around the transition between the Beg an Arreun and Prioldy Formations which underlie the Le Fret Formation. These last three units are of early late Emsian age and comparable to the lower and middle parts of the Marrettes Formation (Vidal et al., 2011).

Several possible morphological trends may be recognised within the hamidi group (Fig. 9). The main trend of these is involved with the original concept of Chatterton et al. (2006) including C. hamidi and C. ranuncula. Smeenk's Otarion aff. druida already bears features characteristic of stratigraphically higher species of this trend including a weakly vaulted cephalon; narrow interocular fixigenae; weakly inflated, bulb-shaped, median glabellar lobe; large (short) eyes; evenly spaced, ubiquitous and uniformly sized cephalic ornament. Developments that occurred in the uppermost Emsian to Eifelian include, typically, increased L1 size (tr.) and reduction of genal spine thickness and length (while retaining its posterolateral direction). An increase in eye size peaked in the middle Eifelian whereas the earlier L1 size increase, reversed in some species (e.g. $C$. ranuncula). The origin of $C$. goerlichi and $C$. lerougei and their position in the diagram are somewhat contentious. Both are considered to be basal taxa of the hamidi group in bearing most of the primitive characters. On the other hand, they already differed markedly from coeval members of the main trend in having several conspicuous features in common: very robust genal spines; scant cephalic ornament; short, rounded median glabellar lobe that slightly overhangs anteriorly. These dissimilarities suggest that $C$. goerlichi and $C$. lerougei evolved from a different early Emsian ancestor and that they are only convergent on basal hamidi group members. If this is true then the hamidi group is at least diphyletic. However, as already explained above, our Cyphaspis groups are based on overall similarities between species and thus not necessarily monophyletic.

A second major trend developed in the lower Eifelian; it includes taxa formerly treated as subspecies of $C$. unguloides (cf. van Viersen \& Prescher, 2007). The cephalic ornament is ubiquitous but can be sparse and of increased size on and near the anterior to lateral cephalic borders; median glabellar lobe is comparatively strongly inflated, but very rarely overhanging anteriorly, and posterolaterally distinctly incised by large, teardrop-shaped L1; small pits on the librigenal field near the lateral border furrow are sometimes seen; eyes are comparatively small for members of the hamidi group; the numbers of pygidial axial rings (six) and pygidial pleurae (five) are clearly increased. Species belonging to this trend are rarely known from complete specimens. Basse (1997, pl. 11, fig. 2b) illustrated two articulated specimens of $C$. aff. unguloides which show the base of a spine on the sixth thoracic axial ring. Van Viersen \& Prescher (2007) recorded a thorax of $C$. belgica (a species considered by them to be closely allied with $C$. unguloides) which also has a well developed dorsal spine. 


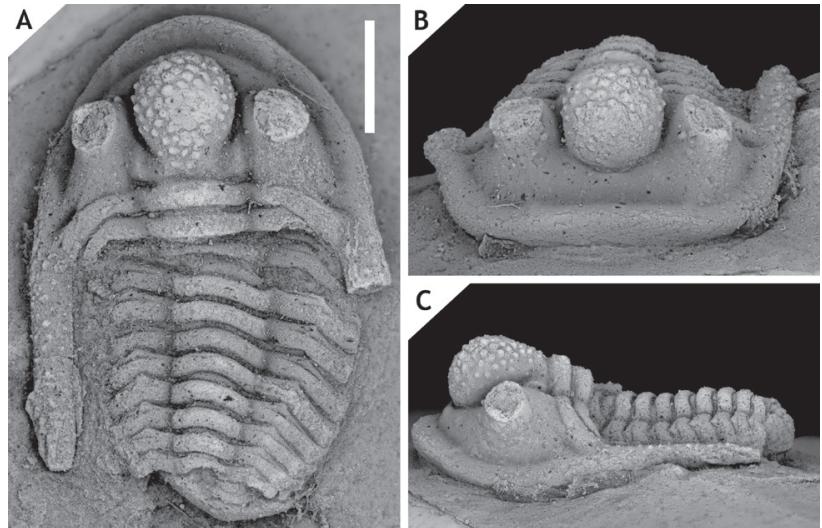

Figure 10. Cyphaspis goerlichi (Haas, 1968) from the Gebze Formation at Tuzla, upper Emsian, Turkey. Holotype complete specimen STIPB-HAAS-14/1, in dorsal (A), oblique anterior (B), lateral (C) views. Scale bar is $2 \mathrm{~mm}$.

Cyphaspis goerlichi (Haas, 1968)

(Fig. 10)

* 1968 Otarion (Otarion) goerlichi Haas, pp. 89-91, fig. 12, pl. 28, fig. 9 .

1977 Otarion (Otarion) goerlichi Haas, 1968; Kobayashi \& Hamada, p. 148.

1981 O. (C.) goerlichi Haas, 1968; Přibyl \& Vaněk, p. 174 [as a species of Otarion (Conoparia)].
2007 Cyphaspis? goerlichi (Haas, 1968); van Viersen \& Prescher, p. 160, fig. 3.

Material. STIPB-HAAS-14/1, holotype complete specimen from the Gebze Formation at the Tuzla locality, Turkey, upper Emsian.

Discussion. Cyphaspis goerlichi has rarely been mentioned in the literature and was omitted from lists of valid species of Otarion and Cyphaspis by Adrain \& Chatterton $(1994,1996)$. This species is very similar to $C$. lerougei from Morocco in having a moderately weakly inflated, subcircular median glabellar lobe that slightly overhangs anteriorly; ornament on median glabellar lobe consists of large tubercles that are weaker and less numerous frontally on this lobe; elongate, weakly inflated L1 bearing three faint tubercles along its length axis; occipital ring, cephalic borders, preglabellar and genal fields all bear comparatively few, fine granules or are devoid of ornament; anterior to lateral cephalic borders are weakly inflated (dorsally flattened); posterior border furrow of cephalon is very weakly impressed whereas it is short (tr.) and deep abaxial of sutural ridge; genal spine is very robust proximally, acuminate or blunted distally, covered with numerous coarse granules; occipital and sixth thoracic axial ring bear a small median tubercle.

Cyphaspis goerlichi is discriminated from C. lerougei through its generally narrower (tr.) cephalic morphology with a higher parabolic outline; slightly more elongate, more teardrop-shaped median glabellar lobe which is slightly
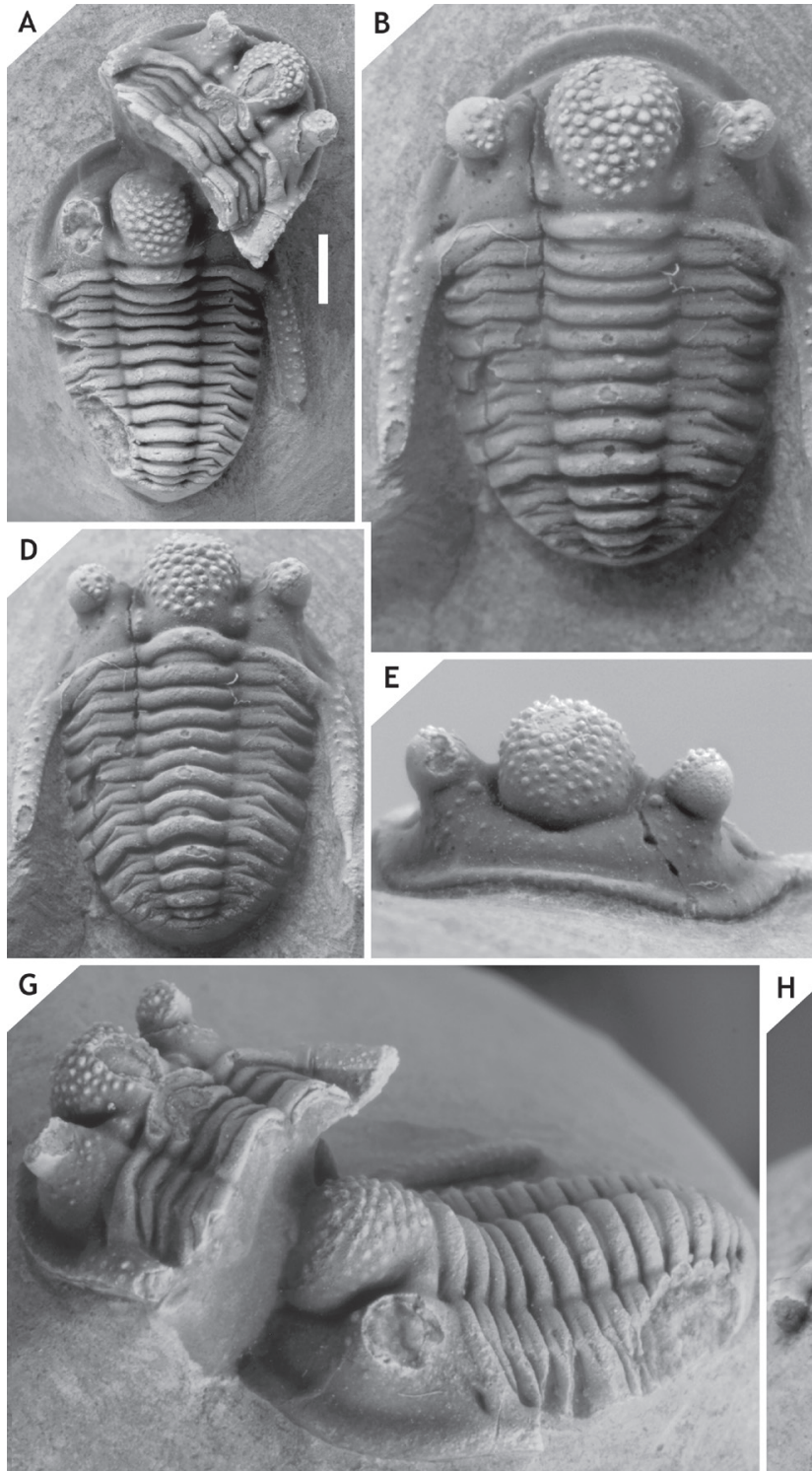
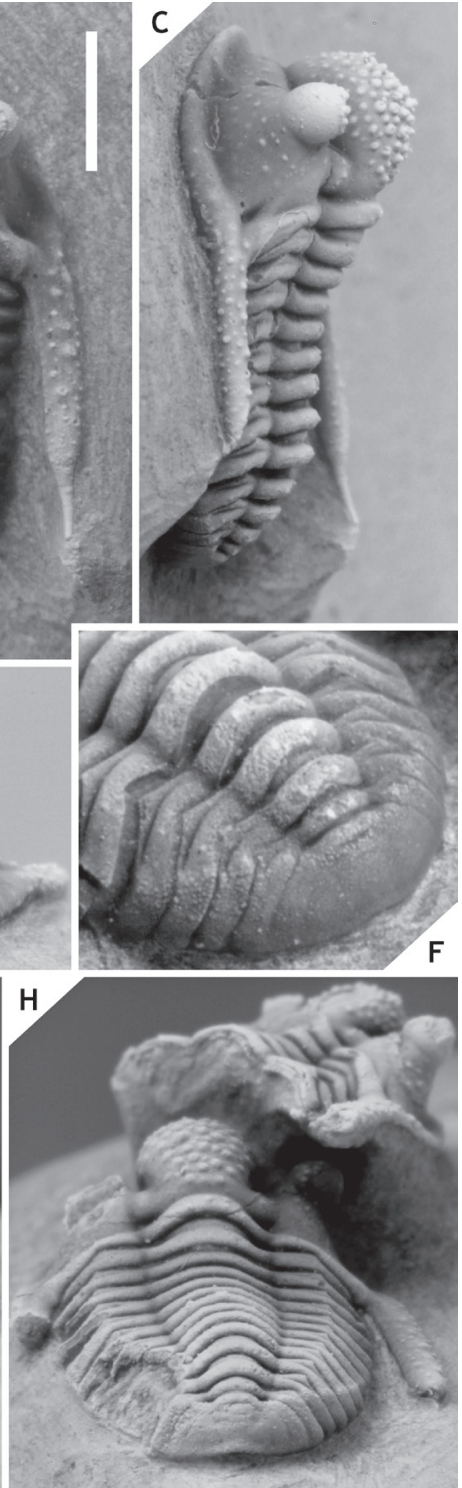

Figure 11. Cyphaspis lerougei sp. nov. from the Hollardops Limestone, Khebchia Formation, at Tadachacht, basalmost upper Emsian, Morocco. Paratype cephalon IRSNB a13015 and paratype complete specimen IRSNB a13016, in dorsal (A), lateral $(\mathrm{G})$, posterior $(\mathrm{H})$ views. Holotype complete specimen IRSNB a13014, in dorsal (B), lateral (C), oblique dorsal (D), oblique anterior (E), oblique posterolateral (F) views. All specimens are on a single rock slab. Scale bars are $2 \mathrm{~mm}$. 

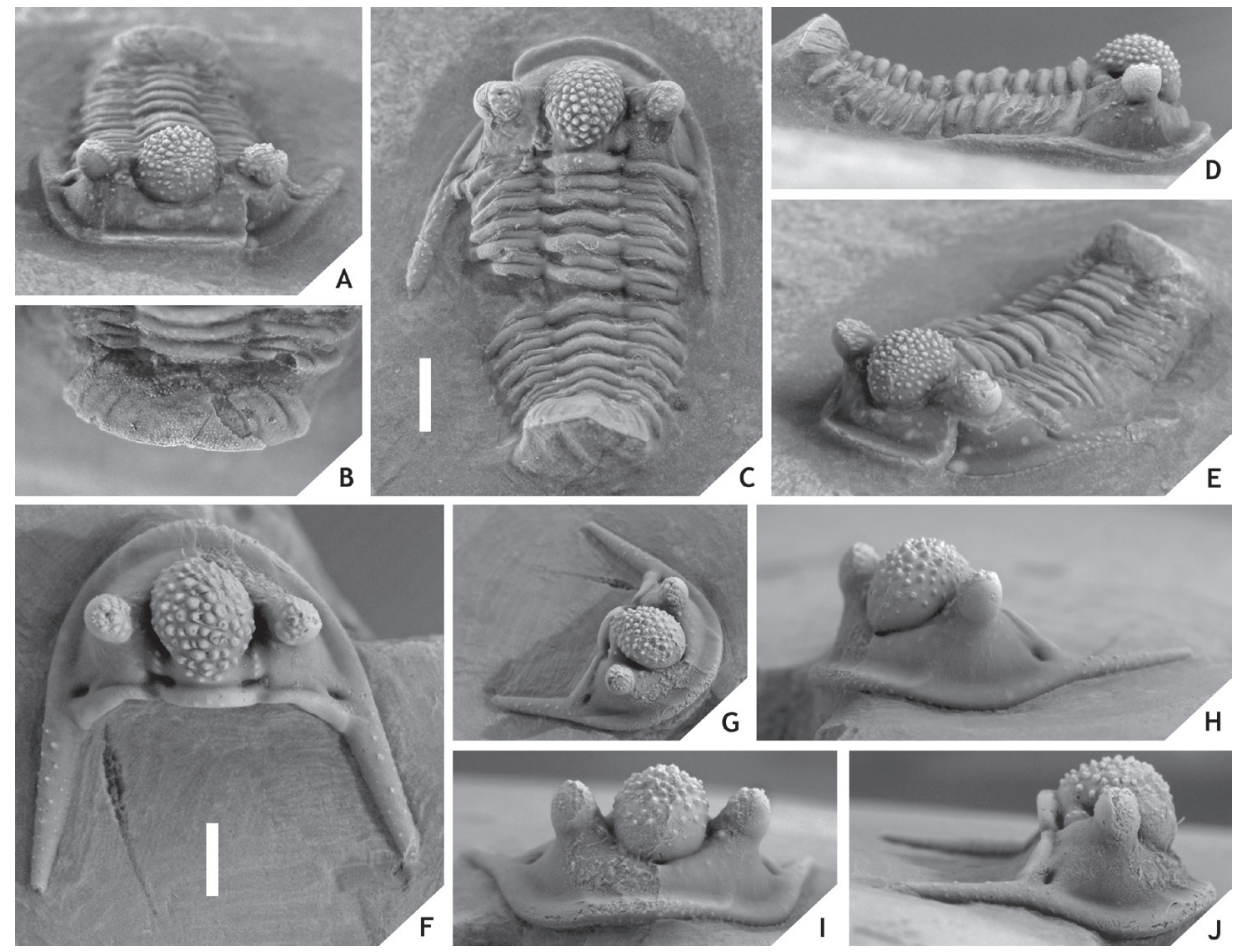

sunken in between the fixigenae; longer L1; smaller Fx4; longer (sag., exsag.), more strongly inflated anterior to lateral cephalic borders; thicker and longer genal spines.

\section{Cyphaspis lerougei sp. nov.}

(Figs 11, 12)

Etymology. Named after Frederik Lerouge.

Holotype. IRSNB a13014, complete specimen (Fig. 11B-F).

Paratypes. IRSNB a13015, a13016, respectively a cephalon with thorax segments attached and a complete specimen, together on the same rock slab as the holotype; IRSNB a12998, a complete specimen; IRSNB a12999, a cephalon.

Type locality and horizon. Tadachacht locality, Morocco; Hollardops Limestone, Khebchia Formation, basalmost upper Emsian.

Diagnosis. Member of the hamidi group with dorsally flattened anterior cephalic border; subcircular median glabellar lobe; genal spine is very robust proximally, blunted distally and subsequently extended as a thin spine; cephalic border, librigenal, fixigenal and preglabellar fields bear few, weak granules concentrated near the eye; pygidium with two well developed axial rings; a third pygidial axial ring is weakly indicated only medially.
Description. Cephalon is scantily ornamented; Fx1 and Fx4 are retained in large holaspides; preglabellar field bears a row of granules; librigena bears few, randomly scattered granules; occipital ring bears a median tubercle with a few weak granules nearby; eyes are somewhat outward directed, overhanging the librigenal field. Anterior two thoracic axial rings bear a single median granule; each consecutive ring bears more granules; sixth axial ring bears a median tubercle; posterior pleural bands each bear two granules. Small pygidium that is almost entirely covered by posterior tegimen consisting of exceedingly finely grained and densely spaced granules that become slightly larger anteriorly; posterior border is upturned medially.

Discussion. One of the paratypes (Fig. 12F-J) has slightly outward projected and more smoothly tapered genal spines. It is not clear at this point whether these differences should be attributed to intraspecific variation.

\section{Cyphaspis cf. lerougei sp. nov.}

(Fig. 13)

Material. Cephalon with several thorax segments attached (IRSNB a13000), of uncertain stratigraphic origin (Emsian?) at the Jbel Issoumour locality.

Discussion. This specimen is similar to C. lerougei yet it also shares characters with $C$. kippingi including a fine, small dorsal spine on the sixth thoracic segment; long,
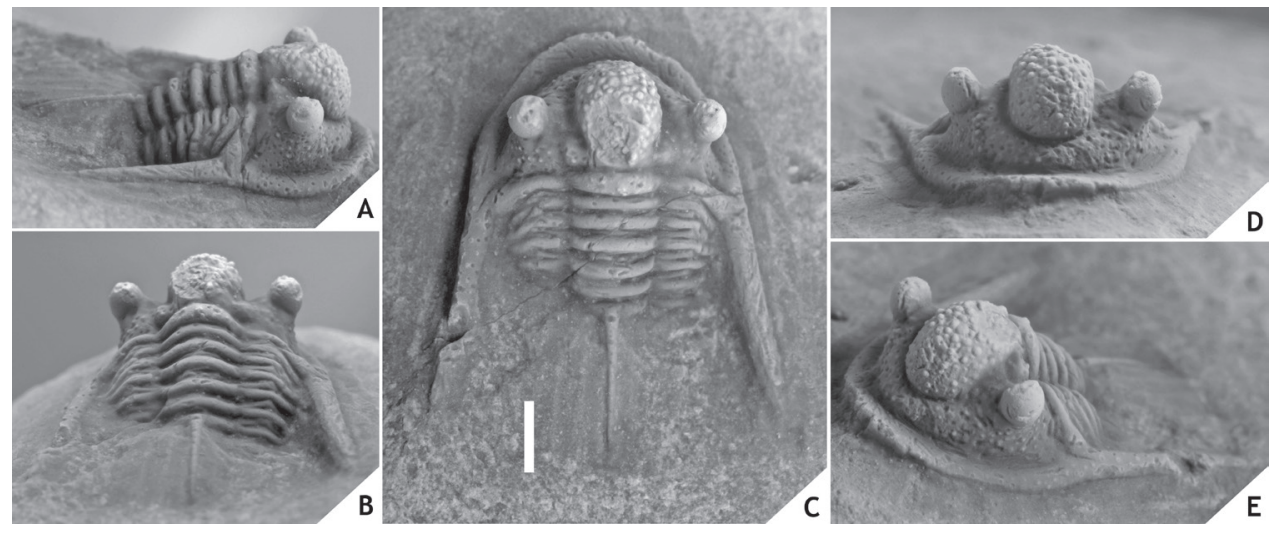

Figure 13. Cyphaspis cf. lerougei sp. nov. of uncertain stratigraphic origin (Emsian?), at Jbel Issoumour, Morocco. Complete specimen IRSNB a13000, in lateral (A), posterior (B), dorsal (C), anterior (D), oblique anterolateral (E) views. Scale bar is $2 \mathrm{~mm}$. 


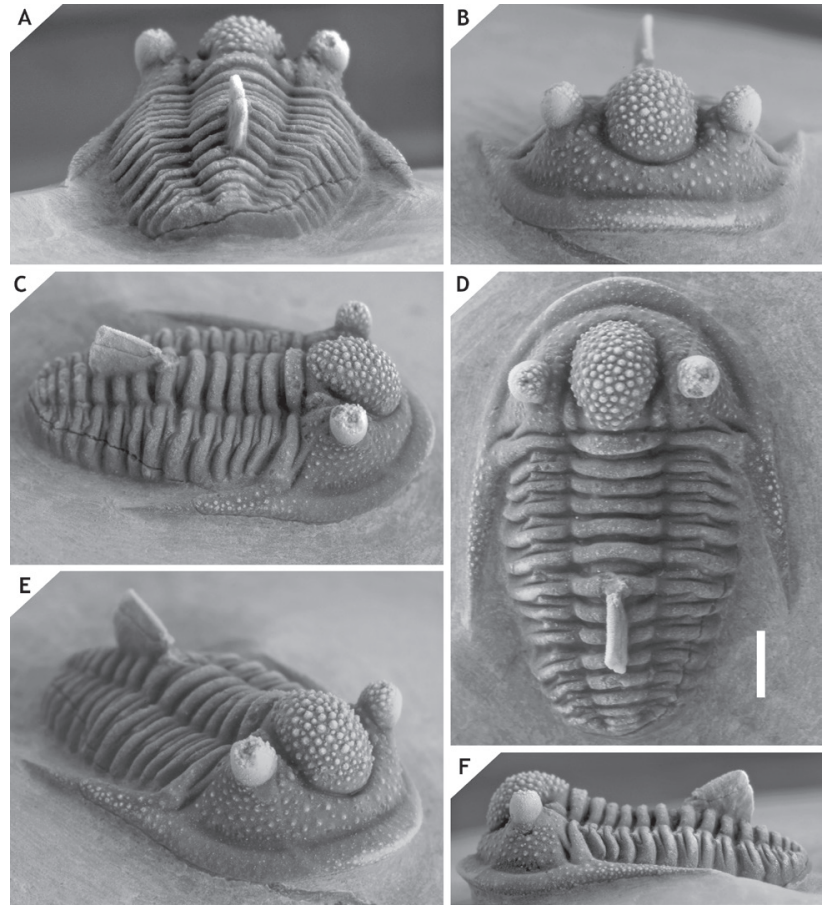

Figure 14. Cyphaspis kippingi sp. nov. from level just below the "Psychopyge couche", Tazoulait Formation, at Issoumour1, upper Emsian, Morocco. Holotype complete specimen IRSNB a13012, in posterior (A), anterior (B), oblique lateral (C), dorsal (D), oblique anterolateral (E), lateral (F) views. Scale bar is $2 \mathrm{~mm}$.

comparatively robust but steadily tapered genal spines; slightly high parabolic cephalic outline; dorsally flattened anterior to lateral cephalic borders. We did not position it in the diagram because we do not know its exact origin other than the indication that it comes from Jbel Issoumour (not necessarily equivalent to any of our Issoumour localities). An Emsian age may be inferred from its morphological resemblances to the other two mentioned species.

\section{Cyphaspis kippingi sp. nov.}

(Figs 14, 15)

\section{Etymology. Named after Michael Kipping.}

Holotype. IRSNB a13012, complete specimen (Fig. 14).

Paratype. IRSNB a12997, a complete specimen of uncertain origin; in all probability from the type locality and horizon.

Type locality and horizon. Issoumour1 locality, Morocco; level just below the "Psychopyge couche", Tazoulait Formation, upper Emsian.

Diagnosis. Member of the hamidi group with a weakly inflated anterior cephalic border; proximally robust and distally acuminate, sword-shaped genal spines with dense granulation; small dorsal spine on the sixth thoracic axial ring; thorax is devoid of prosopon except for the posterior tegimen abaxially on segments 9 to 11 .

Discussion. Cyphaspis kippingi has been positioned in the diagram as an intermediary form between Otarion aff. druida and $C$. hamidi. Some of the features of basal members of the hamidi group are retained such as the long genal spines that are covered with granules; weakly inflated, weakly dorsally arched anterior cephalic border. At the same time C. kippingi bears resemblances to stratigraphically younger $C$. hamidi and $C$. foumzguidensis including a bulb-shaped median glabellar lobe that does not overhang anteriorly; elongate, weakly inflated L1; cephalon with ubiquitous, evenly spaced tubercles that are only slightly larger and more closely spaced on the median glabellar lobe.

The paratype differs from the holotype only in that it bears fewer granules on the fixigena, librigenal field and genal spine; a row of five granules on each thoracic axial ring; and a better developed posterior tegimen. These last two differences may be explained by the slightly poorer preservation of the thorax and pygidium of the holotype.

Cyphaspis foumzguidensis sp. nov.

(Fig. 16)

Etymology. Named after its geographic occurrence.

Holotype. IRSNB a12996, complete specimen.

Type locality and horizon. Foum Zguid locality, Morocco; ZGEE3, Timrhanrhart Formation, lower Eifelian.

Diagnosis. Member of the hamidi group with a comparatively weakly vaulted (tr.) cephalon; occipital ring is as high as median glabellar lobe; median glabellar lobe is weakly inflated even for a member of the group, dorsally flattened and only slightly ascending above the eyes; small, teardrop-shaped L1 the anterior tip of which is lateral to $\varepsilon$; preglabellar and librigenal fields bear very dense granulation.

Discussion. Cyphaspis hamidi from stratigraphically lower levels (ZGEE1 and ZGEE2) at the nearby Zguilma locality is similar to C. foumzguidensis yet distinctly different in having a more strongly inflated median glabellar lobe; longer, more inflated L1; larger eyes; narrower (tr.) librigenal field lateral of the eye, with fewer granules. The new species is common in ZGEE3 at our Foum Zguid locality yet strikingly, members of the hamidi group are absent (or perhaps very rare) in the lower ZGEE1 and ZGEE2 levels here.

Khaldi et al. (2016) described a cephalon from the Chefar el Ahmar Formation (upper Emsian) in Algeria which they tentatively identified as $C$. hamidi. This specimen is an indeterminate member of the hamidi group and likely represents a new species. Of note is that it has three tubercle pairs on the preglabellar field which occur sporadically in species of Otarionini (cf. van Viersen \& Prescher, 2014).
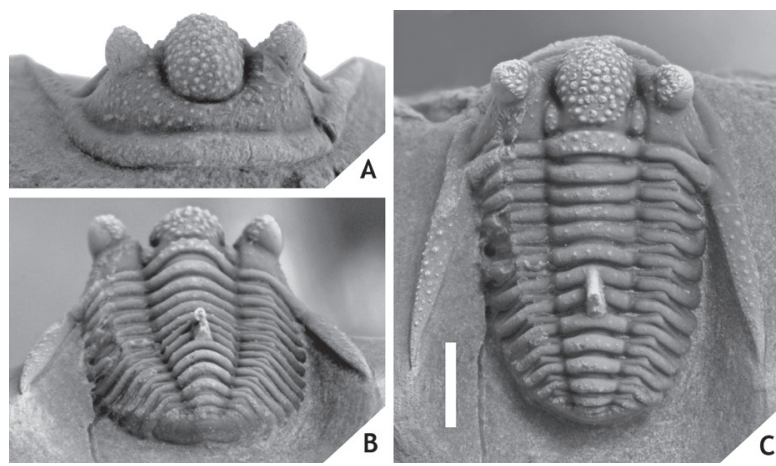

Figure 15. Cyphaspis kippingi sp. nov. presumably from level just below the "Psychopyge couche", Tazoulait Formation, at Issoumour1, upper Emsian, Morocco. Paratype complete specimen IRSNB a12997, in anterior (A), posterior (B), dorsal (C), lateral (D), anterolateral (E) views. Scale bar is $2 \mathrm{~mm}$. 

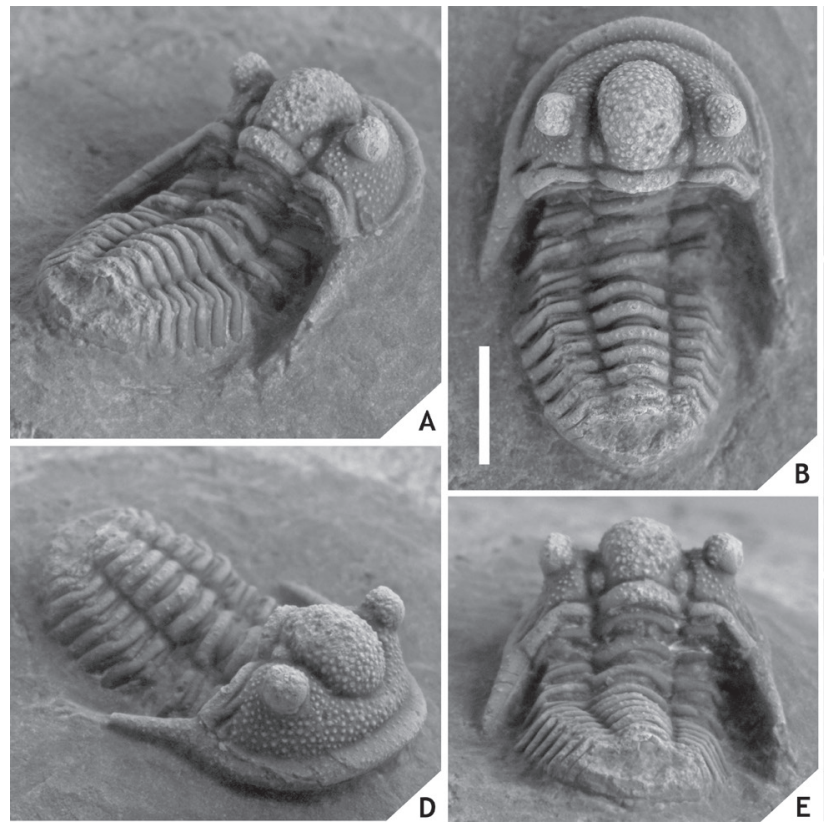

Cyphaspis juergenhollandi sp. nov. (Fig. 17)

\section{cf. 1969 Otarion (Otarion) sp. D; Alberti, pl. 34, fig. 7.}

Etymology. Named after Jürgen Holland.

Holotype. IRSNB a13013, complete specimen.

Type locality and horizon. Talawarite locality, Morocco; interval between the "Gerastos and Hollardops couches", Amerboh Group, upper Emsian.

Diagnosis. Member of the hamidi group with small, inflated anterior and posterior subocular patches; preglabellar, fixigenal and librigenal fields as well as frontal part of median glabellar lobe covered by moderately closely spaced granules; straight, fairly long genal spine with inward curved tip; small, narrow median glabellar lobe bearing tightly packed tubercles dorsally; median tubercle on occipital ring and serially homologous ones on thoracic axial rings 1, 2, 4, 5-8; from third thoracic axial ring backwards, each consecutive ring bears more tubercles.

Discussion. Cyphaspis juergenhollandi is much more similar to stratigraphically lower species than to roughly coeval $C$. hamidi. When positioning $C$. juergenhollandi in the diagram we considered some of its similarities to $C$. lerougei and $C$. goerlichi including the elongate but weakly inflated L1; teardrop-shaped median glabellar lobe bearing better developed ornament dorsally than frontally and on remainder of cephalon; long genal spines; similar configuration of tubercles on thoracic axial rings. However, the teardrop-shaped median glabellar lobe and genal spines of $C$. juergenhollandi could also be interpreted as narrower versions of $C$. kippingi while these two species furthermore share similar cephalic ornament (e.g. numerous fine granules on anterior to lateral cephalic borders; widely spaced tubercles on preglabellar and librigenal fields).

Alberti (1969) recorded a damaged cranidium with attached right librigena of Otarion (Otarion) sp. D from the Emsian/ Eifelian transition in southeast Morocco. His specimen is generally similar to the holotype of $C$. juergenhollandi but its limited preservation precludes a detailed comparison.

\section{Cyphaspis smeenki sp. nov.}

(Fig. 18)

Etymology. After Zwier Smeenk, in recognition of his work on Devonian trilobites.

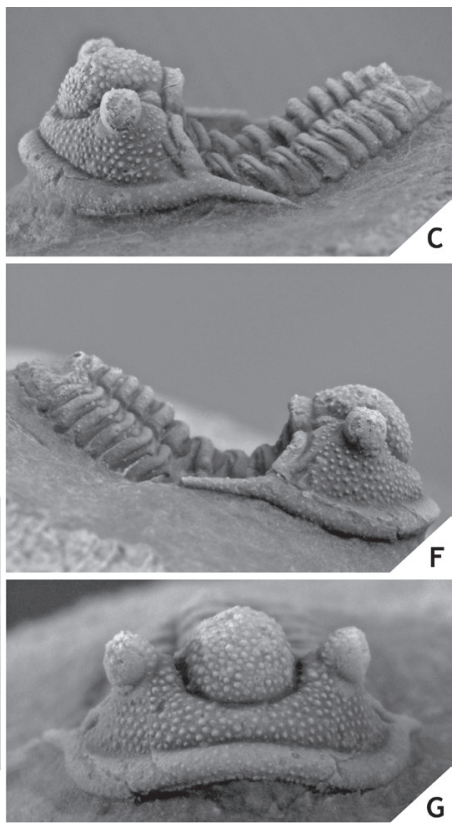

Figure 16. Cyphaspis foumzguidensis sp. nov. from ZGEE3, Timrhanrhart Formation, at Foum Zguid, lower Eifelian, Morocco. Holotype complete specimen IRSNB a12996, in oblique posterolateral (A), dorsal (B), left lateral $(\mathrm{C})$, oblique anterolateral (D), posterior (E), right lateral $(\mathrm{F})$, anterior $(\mathrm{G})$ views. Scale bar is $2 \mathrm{~mm}$.

Holotype. IRSNB a13009, complete specimen.

Type locality and horizon. Boudib locality, Morocco; El Otfal Formation, Eifelian.

Diagnosis. Member of the hamidi group with an exceedingly scantily ornamented cephalon; median glabellar lobe bearing widely spaced granules; genal spine entirely straight, gently tapered; cephalic outline subtrapezoidal; dorsoventrally high anterior to lateral cephalic borders of subrectangular crosssection; shallow anterior to lateral cephalic border furrows.

Discussion. Cyphaspis smeenki displays an unusual combination of features that does not fit any specific trend of the hamidi group. These include a very long thoracic spine; sparse granules on the median glabellar lobe and absence of ornament elsewhere on the cephalon. We have linked $C$. smeenki to $C$. kippingi in the diagram although this is primarily based on the straight, posterolaterally directed genal spines
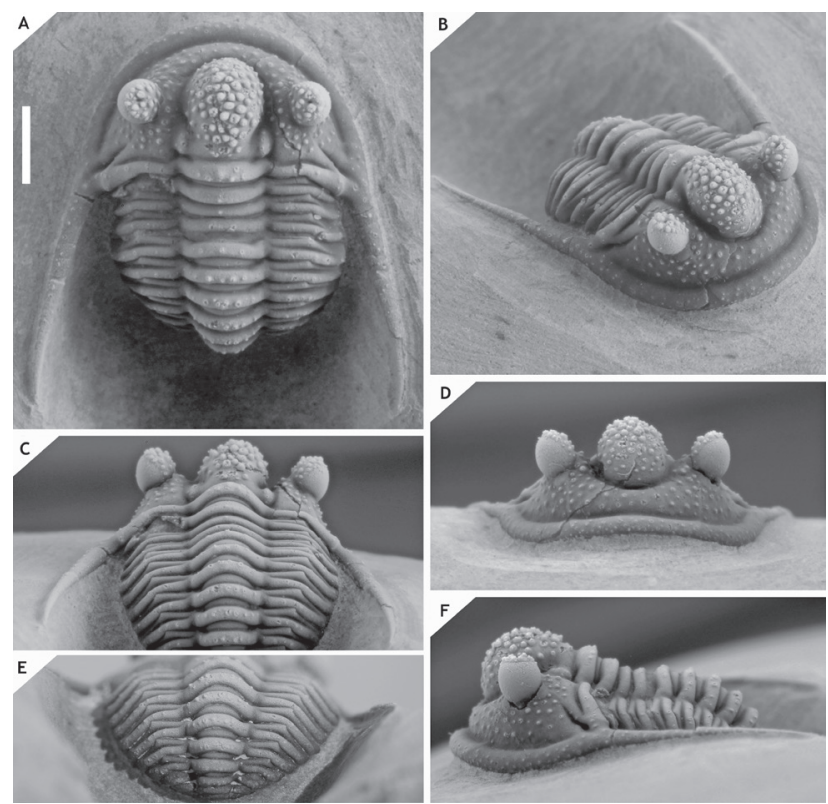

Figure 17. Cyphaspis juergenhollandi sp. nov. from interval between the "Gerastos and Hollardops couches", Amerboh Group, at Talawarite, upper Emsian, Morocco. Holotype complete specimen IRSNB a13013, in dorsal (A), oblique anterolateral (B), close-up of first nine thorax segments (C), anterior (D), close-up of thorax from sixth segment and including pygidium (E), lateral $(F)$ views. Scale bar is $2 \mathrm{~mm}$. 

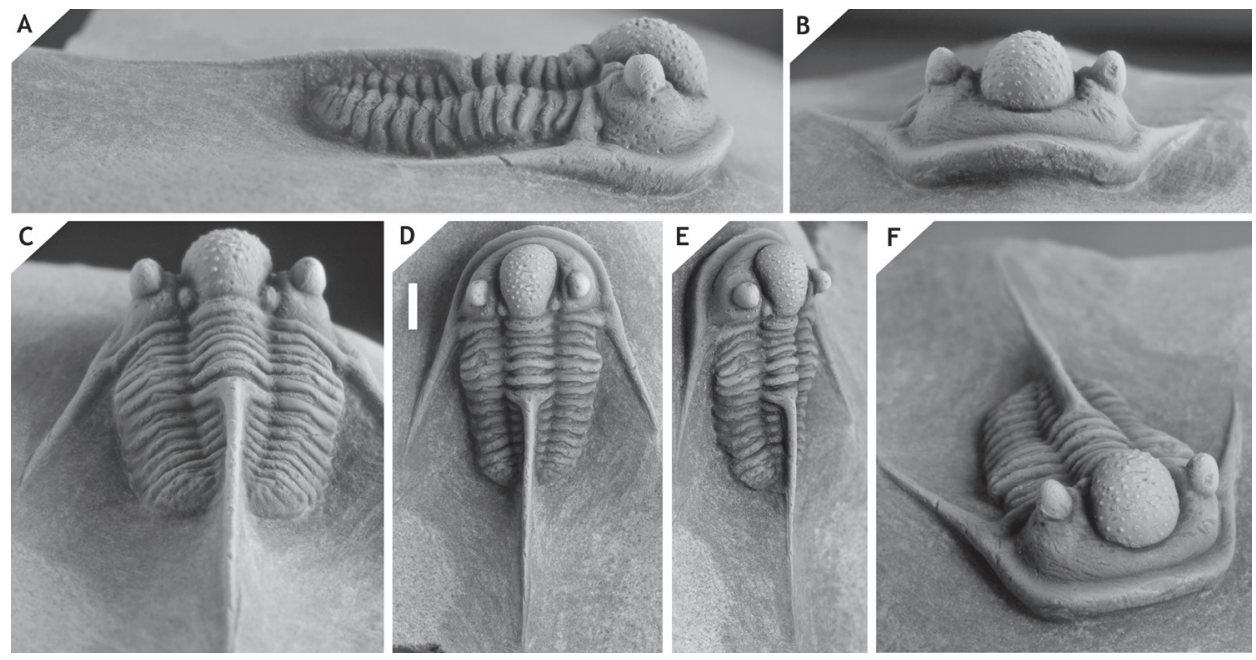

Figure 18. Cyphaspis smeenki sp. nov. from the El Otfal Formation at Boudib, Eifelian, Morocco. Holotype complete specimen IRSNB a13009, in lateral (A), anterior (B), posterior (C), dorsal (D), oblique lateral (E), oblique anterolateral $(\mathrm{F})$ views. Scale bar is $2 \mathrm{~mm}$. and similar inflation of cephalic parts. The dorsoventrally high anterior to lateral cephalic borders are also seen in $C$. goerlichi but that species is otherwise rather dissimilar.

The occipital ring of $C$. smeenki is unusual in that it is obliquely posteriorly directed. Strictly taken (i.e., when the occipital ring is held in the vertical plane), the median glabellar lobe is positioned far anteriorly relative to the rest of the cephalon and even overhangs the anterior cephalic margin. We do not consider such an anteriorly overhanging glabella to be consistent with the weak inflation and overall cephalic morphology of this species. A normal 'resting' position is preferred in the dorsal description and photograph of its cephalon.

\section{Cyphaspis sp. I}

\section{(Fig. 19)}

Material. A cephalon with attached thorax segments (IRSNB a13008), from the Eifelian or Givetian at Jbel Issoumour.

Discussion. A single specimen of Cyphaspis sp. I is recorded which is of Eifelian or Givetian provenance at Jbel Issoumour (pers. comm. DH with local workers in 2015). There are only two similar forms to $C$. sp. I that we know. One is a paratype cephalon of Cyphaspis balanops (see Basse, 2002, pl. 28, fig. 573) from the middle Eifelian in Germany which shares the exceptionally broad anterior to lateral cephalic border furrows. The other is a large morphotype of $C$. unguloides described by van Viersen \& Prescher (2007, p. 161, pl. 1, fig. 7) from the lower Eifelian in Germany. The Moroccan taxon only differs significantly from the latter in having broad, very well-developed anterior to lateral cephalic border furrows; longer genal spines; slightly less pronounced cephalic ornament. Cyphaspis sp. I has a continuous row of small pits just interior to the anterior to lateral cephalic border furrow. This is generally a rare feature among Cyphaspis species yet again it is known in $C$. unguloides where it is weak and obscured by granules. A more straightforward example is a librigena of coeval and morphologically similar $C$. belgica illustrated by van Viersen $\&$ Prescher (2007, pl. 2, fig. 2). Based on these analogies to the Ardenno-Rhenish species we believe that our specimen is of Eifelian rather than Givetian age.

\section{Cyphaspis agayuara group}

Assigned taxa. Cyphaspis buchbergeri Adrain \& Chatterton, 1996, Silurian, Canada; Cyphaspis elachopos Thomas, 1978, Silurian, England; Cyphaspis lowei Adrain \& Chatterton, 1996, Silurian, Canada; Cyphaspis mactavishi Adrain \& Chatterton, 1996, Silurian, Canada; Cyphaspismunii Adrain \& Chatterton, 1996, Silurian, Canada; Cyphaspis carrolli Adrain \& Kloc, 1997, Lochkovian, US; Cyphaspis heisingi sp. nov., Pragian, Morocco; Cyphaspis maharchensis sp. nov., Pragian, Morocco; Cyphaspis agayuara Chatterton et al., 2006, Emsian, Morocco; Cyphaspis barbarossa Basse, 1997, Emsian, Germany; Cyphaspis eberhardiei Chatterton et al., 2006, Emsian, Morocco; Cyphaspis frankeorum Basse, 2006, Emsian, Luxemburg; Cyphaspis khraidensis sp. nov., Emsian, Morocco; Cyphaspis tadachachtensis sp. nov., Emsian, Morocco; Cyphaspis ihmadii sp. nov., Givetian, Morocco. Additional taxa: Cyphaspis cf. khraidensis sp. nov., Emsian, Morocco; Cyphaspis ?agayuara of Khaldi et al. (2016), Emsian, Algeria; Cyphaspis cf. eberhardiei (herein), Eifelian, Morocco; Cyphaspis sp. nov. A of Chatterton et al. (2006), Eifelian, Morocco.

Discussion. The agayuara group represents the main rootstock of Cyphaspis including the oldest known species from the Silurian. Its members were widely palaeogeographically distributed in the Lower Devonian whereas only few representatives remained in the Middle Devonian. Adrain \& Kloc (1997) underlined the very
Figure 19. Cyphaspis sp. I, from the Eifelian or Givetian at Jbel Issoumour, Morocco. Cephalon with attached thorax segments IRSNB a13008, in anterior (A), lateral (B), oblique dorsal (C), anterolateral (D), oblique anterolateral (E), close-up of right librigenal border furrow with row of pits $(\mathrm{F})$, posterior $(\mathrm{G})$ views. Scale bar is $2 \mathrm{~mm}$. Notice the anomalous right genal spine.
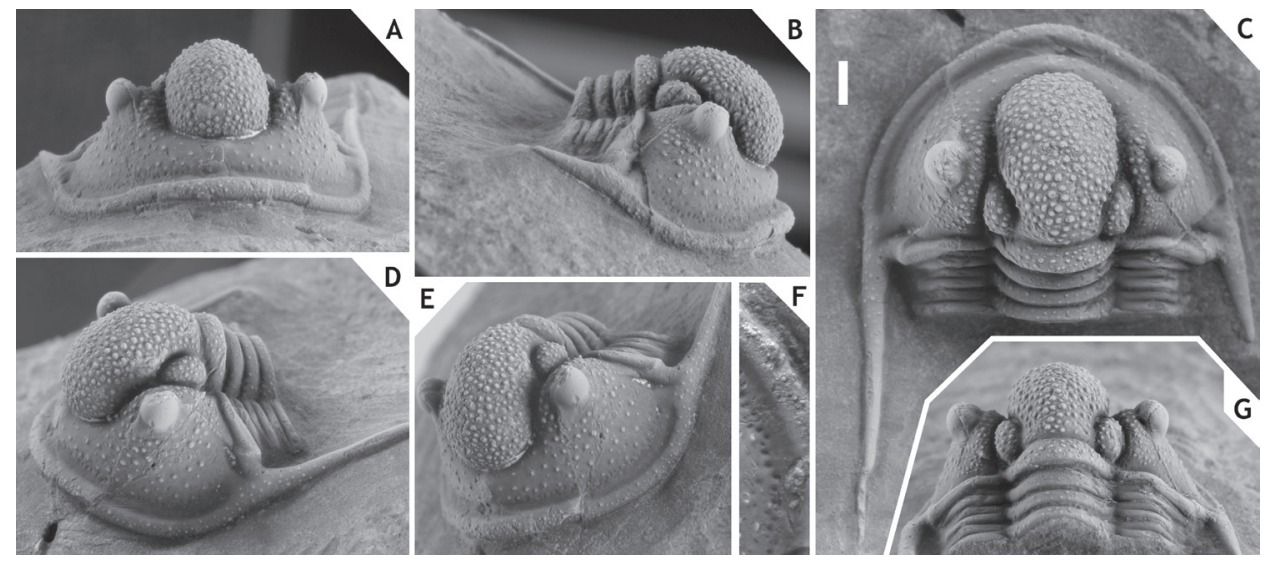
primitive morphology of the Lochkovian C. carrolli which they found to be more similar to Silurian species than to other congeners from the Devonian. Here we describe two Pragian species, $C$. heisingi and $C$. maharchensis, which bear an intermediate morphology between $C$. carrolli and the Emsian C. agayuara. Members of the group are conservative in that they all have many typical (i.e., basal) Cyphaspis features such as a strongly inflated but smoothly rounded median glabellar lobe that overhangs anteriorly; short preglabellar field; moderately long genal spines; small eyes; a well developed spine on the sixth thoracic axial ring; comparatively few pygidial axial rings and pleurae.

There is some controversy in creating the agayuara group while at the same time recognising the other groups under the present assumption that they should all be assigned to Cyphaspis. The exclusion of phylogenetically derived taxa could render the agayuara group as a paraphyletic collection of species with a primitive morphology. It is possible that a future cladistic analysis leads to the conclusion that Cyphaspis should be subdivided but until that time it remains the oldest available name to accommodate species. It must be recollected that in the very hypothetical scenario that each of our Cyphaspis groups should be warranted generic rank, the genus Cyphaspis would encompass the ceratophthalmus group because the latter contains the type species.

Basse (2006) described C. frankeorum based on a tectonically deformed, partially enrolled specimen and noted that there is a certain resemblance to Otarion aff. druida of Smeenk (1983) from the Emsian in Spain. Nevertheless he concluded that detailed comparisons were not feasible because the Spanish taxon is not very well known. Indeed Smeenk's material of $O$. aff. druida has multiple stratigraphic and geographic origins and we do not consider all of his specimens to belong to the same species or even Cyphaspis group (one of Smeenk's cephala, however, is assigned to the hamidi group herein). Cyphaspis frankeorum belongs to the agayuara rather than the hamidi group in having smaller eyes; shorter (sag., exsag.) anterior border; wider interocular fixigenae. Other perspectives than dorsal view were not illustrated by Basse but an internal mould of a cephalon figured and identified as $C$. frankeorum by Franke (2010, pl. 12 , fig. 4) shows that it is comparatively strongly vaulted like other members of the agayuara group.

Cyphaspis maharchensis sp. nov.

(Fig. 20)

Etymology. Named after its geographic occurrence.

Holotype. IRSNB a13007, complete specimen.
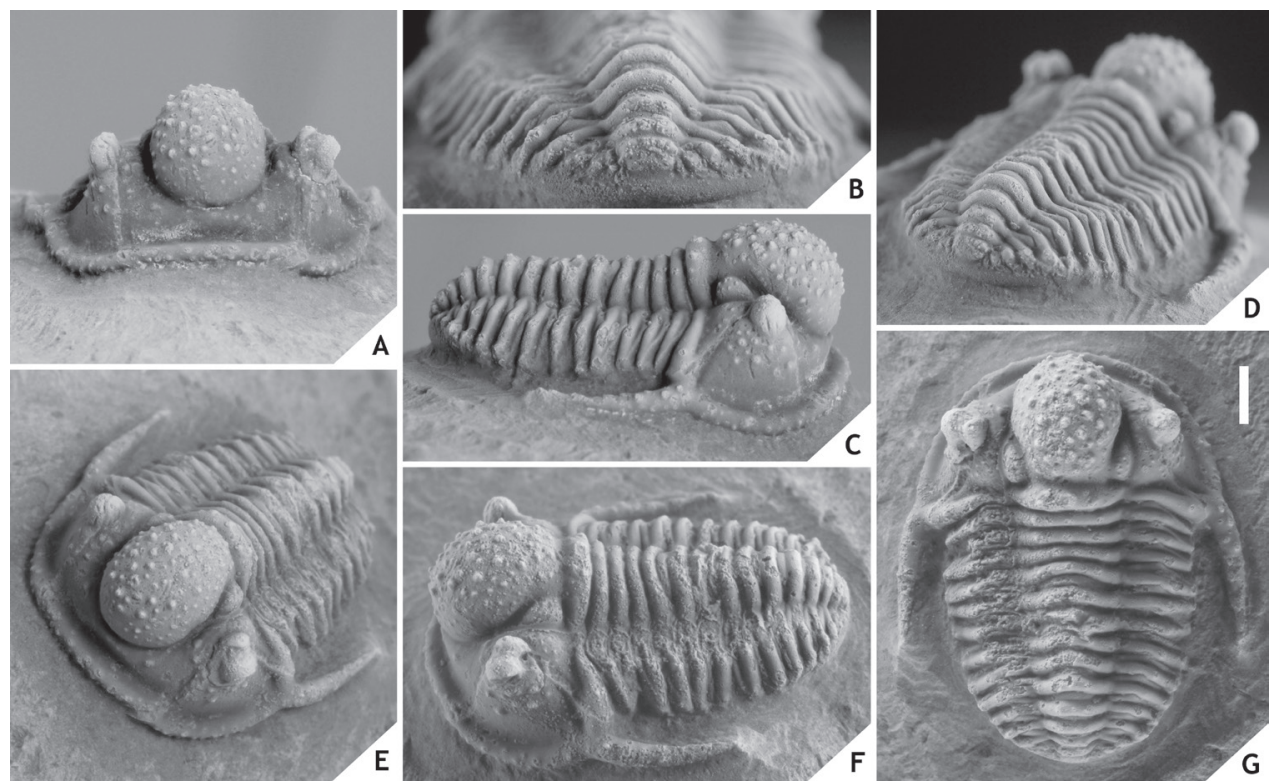

Figure 20. Cyphaspis maharchensis sp. nov. from the "Proetid couche", Ihandar Formation, at Maharch, Pragian, Morocco. Holotype complete specimen IRSNB a13007, in anterior (A), posterior (B), lateral (C), posterolateral (D), oblique anterolateral (E), oblique lateral $(\mathrm{F})$, dorsal $(\mathrm{G})$ views. Scale bar is $2 \mathrm{~mm}$. 


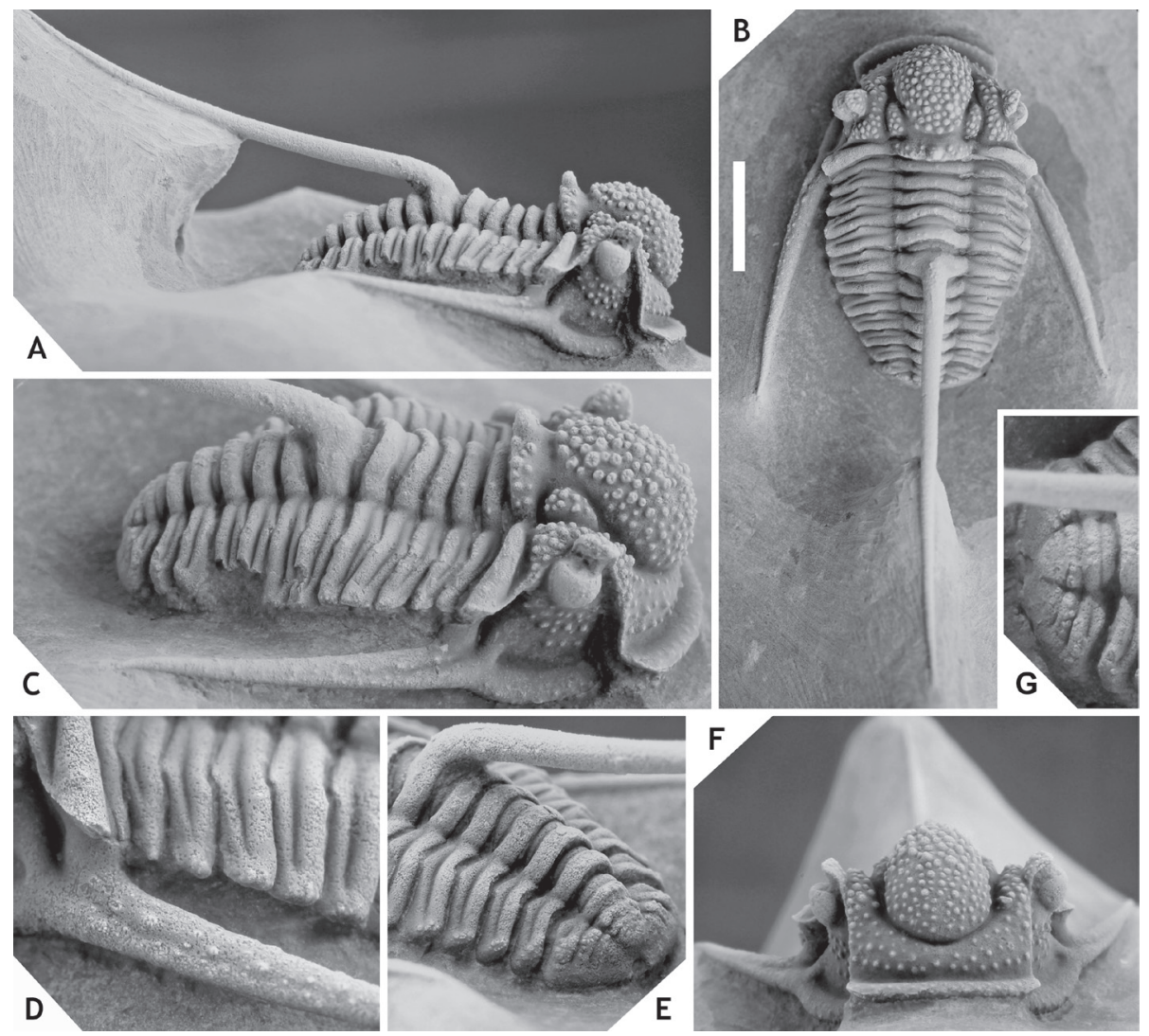

Figure 21. Cyphaspis heisingi sp. nov. from the Assa Formation at Mdâour el Kbîr, Pragian, Morocco. Holotype complete specimen IRSNB a13011, in lateral (A), dorsal (B), oblique lateral (C), close-up of left genal spine and anterior five thoracic pleurae (D), oblique posterolateral $(\mathrm{E})$, anterior (F), close-up of pygidium $(\mathrm{G})$ views. Scale bar is $5 \mathrm{~mm}$.

Type locality and horizon. Mdâour el Kbîr locality, Morocco; Assa Formation, Pragian.

Diagnosis. Member of the agayuara group with high, collar-shaped occipital ring bearing a large median tubercle; large L1; comparatively large eyes (for a member of the group); furrowed genal spines; tubercles on preglabellar field verge to forming three consecutive, border parallel rows; anterior margin of posterior tegimen consists of verrucous tubercles and is extended onto the pleural tips of all thoracic segments.

Description. Short, pear-shaped glabella, somewhat indented by elongate L1; palpebral lobe bears a row of granules on its margin; L1, fixigena, and median glabellar lobe bear closely spaced tubercles; dorsally flattened anterior cephalic border; anterior to lateral cephalic borders bear faint granules on outer half; trench-like anterior and lateral border furrow; genal spines are proximally posterolaterally directed and subsequently slightly convergent, yet they retain a posterolateral direction.

Each thoracic axial ring bears one median granule and two additional granule pairs abaxially; long, well-developed, proximally posteriorly and distally upward directed spine on sixth axial ring; posterior tegimen is visible distally on all pleurae. The thorax is broader across the middle segments than the ones anterior and posterior to these. This feature is also in line with the varying shapes of the pleural tips: in anterior segments the posterior tegimen seems to fortify and extend the posterior pleural band; in posterior segments the posterior tegimen is developed at the cost (tr.) of the posterior pleural band, causing a ventral inclination; these features result in triangular pleural tips whereas thorax segments 5 and 6 have typical subquadrate pleural tips.

Small pygidium with three axial rings and a faint fourth one; anteriormost axial ring is dorsoventrally much higher than the others and separated by a long (sag., exsag.) furrow;
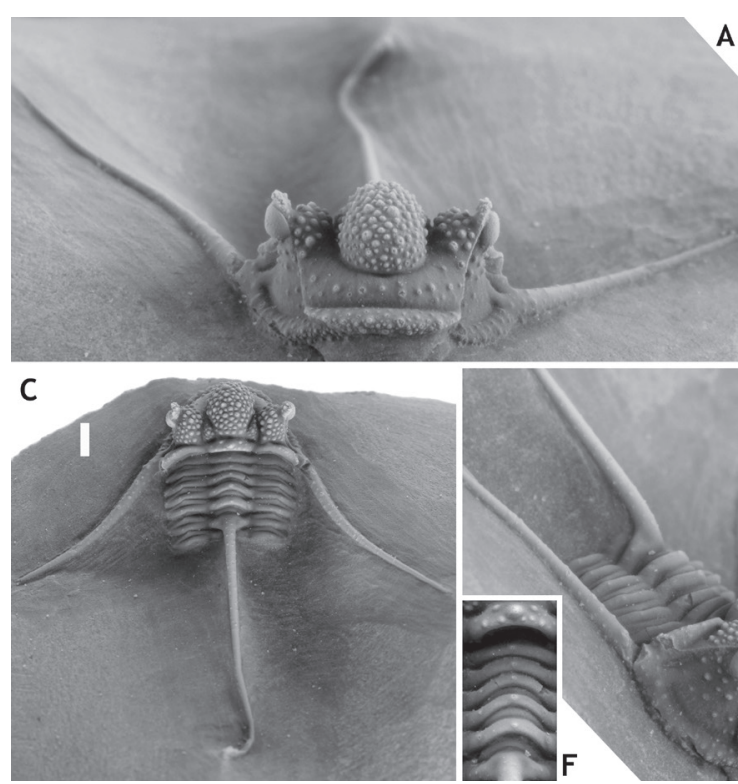
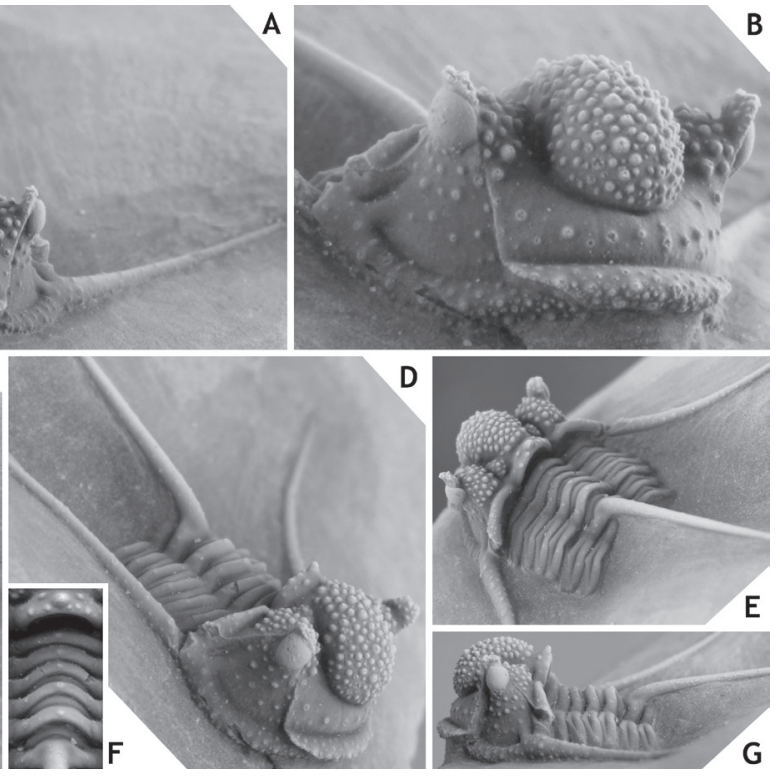

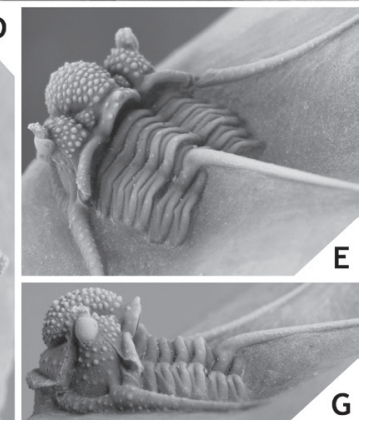

Figure 22. Cyphaspis agayuara Chatterton et al., 2006 from interval between the "Gerastos and Hollardops couches", Amerboh Group at Talawarite, upper Emsian, Morocco. Cephalon with seven tergites attached IRSNB a13005, in anterior (A), anterolateral (B), dorsal (C), oblique anterolateral (D), oblique posterolateral (E), close-up of occipital ring and anterior six thoracic axial rings $(\mathrm{F})$, lateral $(\mathrm{G})$ views. Scale bar is $2 \mathrm{~mm}$. 

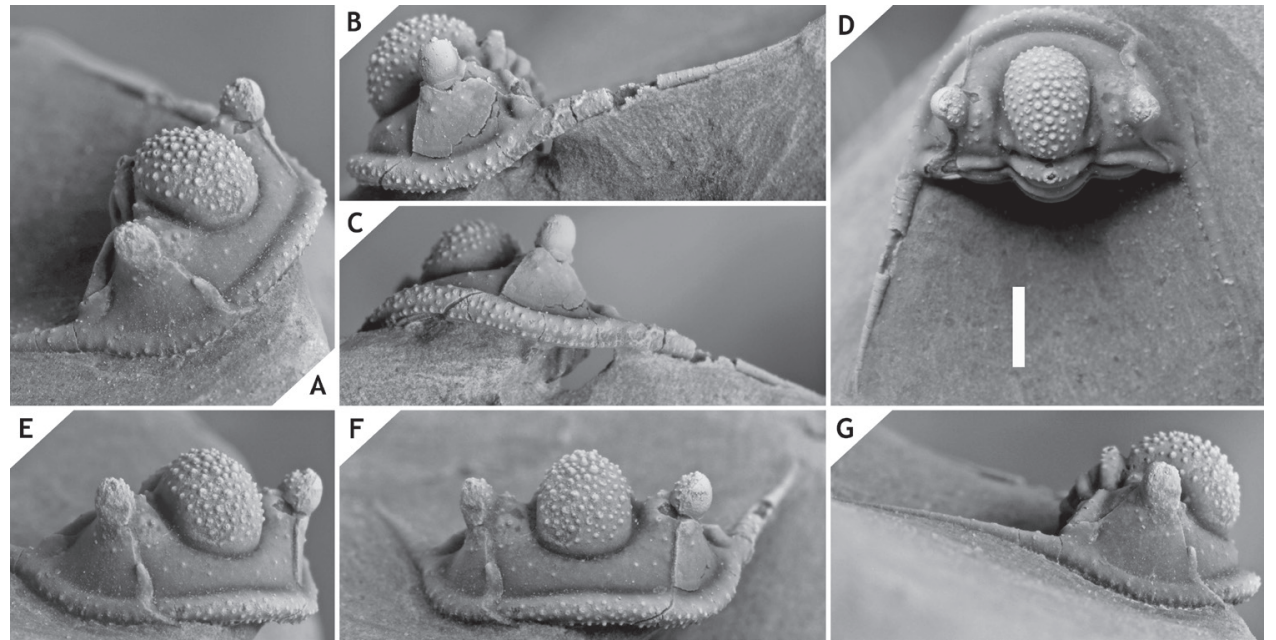

Figure 23. Cyphaspis cf. eberhardiei Chatterton et al., 2006 from ZGEE3, Timrhanrhart Formation, at Foum Zguid, lower Eifelian, Morocco. Enrolled specimen IRSNB a13001, in oblique anterolateral (A), left lateral (B), ventral close-up of cephalic border (C), oblique dorsal (D), anterolateral $(\mathrm{E})$, anterior $(\mathrm{F})$, right lateral $(\mathrm{G})$ views. Scale bar is $2 \mathrm{~mm}$. only adaxial part of first pleural furrow is developed (the rest is obscured by the posterior tegimen).

\section{Cyphaspis agayuara Chatterton et al., 2006} (Fig. 22)

* 2006 Cyphaspis agayuara Chatterton et al., pp. 48, 49, pl. 42 , figs $1-7$.

Material. IRSNB a13005, a cephalon with seven tergites attached, from interval between the "Gerastos and Hollardops couches", Amerboh Group at the Talawarite locality, upper Emsian, Morocco.

Discussion. Our material is almost indistinguishable from the single (holotype) specimen of $C$. agayuara from coeval strata in Zguilma described and figured by Chatterton et al. (2006). We hope that the photos of a second representative of this species are helpful.

Specimens tentatively assigned to this species by Khaldi et al. (2016) have very small eyes and a strongly inflated median glabellar lobe. We regard them as an undescribed (new) species of the agayuara group.

\section{Cyphaspis cf. eberhardiei Chatterton et al., 2006 \\ (Fig. 23)}

Material. IRSNB a13001, partially enrolled specimen from ZGEE3, Timrhanrhart Formation at the Foum Zguid locality, lower Eifelian, Morocco.

Discussion. Chatterton et al. (2006) described Cyphaspis sp. nov. A from ZGEE3 just northeast of their Zguilma locality.
These workers noticed many similarities to C. eberhardiei from ZGEE1 at Zguilma but could not decide whether it belongs to a new species because it could just as well be a $C$. eberhardiei. Our specimen comes from a third locality in the same area and is coeval to $C$. sp. nov. A from which it only clearly differs in having much smaller L1. Our specimen is furthermore different from $C$. eberhardiei in having weak tubercles on the interocular fixigenae; smaller L1; shorter, thinner genal spines. All three taxa are obviously closely allied and so any descriptions of new species are probably best postponed until more material becomes available for comparison.

Cyphaspis khraidensis sp. nov.

(Fig. 24)

Etymology. Named after its geographic occurrence.

Holotype. IRSNB a13004, cephalon.

Type locality and horizon. Khraid locality, Morocco; ZGEE2, Timrhanrhart Formation, upper Emsian.

Diagnosis. Member of the agayuara group with occipital ring bearing a median complex of granules instead of a single tubercle; median glabellar lobe, preglabellar field and anterior half of librigenal field covered with numerous granules; palpebral lobes and anterior to lateral cephalic borders covered with exceedingly closely spaced, fine granules; small eyes.

Discussion. Like the stratigraphically higher $C$. cf. eberhardiei and $C$. sp. nov. A of Chatterton et al. (2006), $C$. khraidensis is also similar to $C$. eberhardiei. Yet the rather
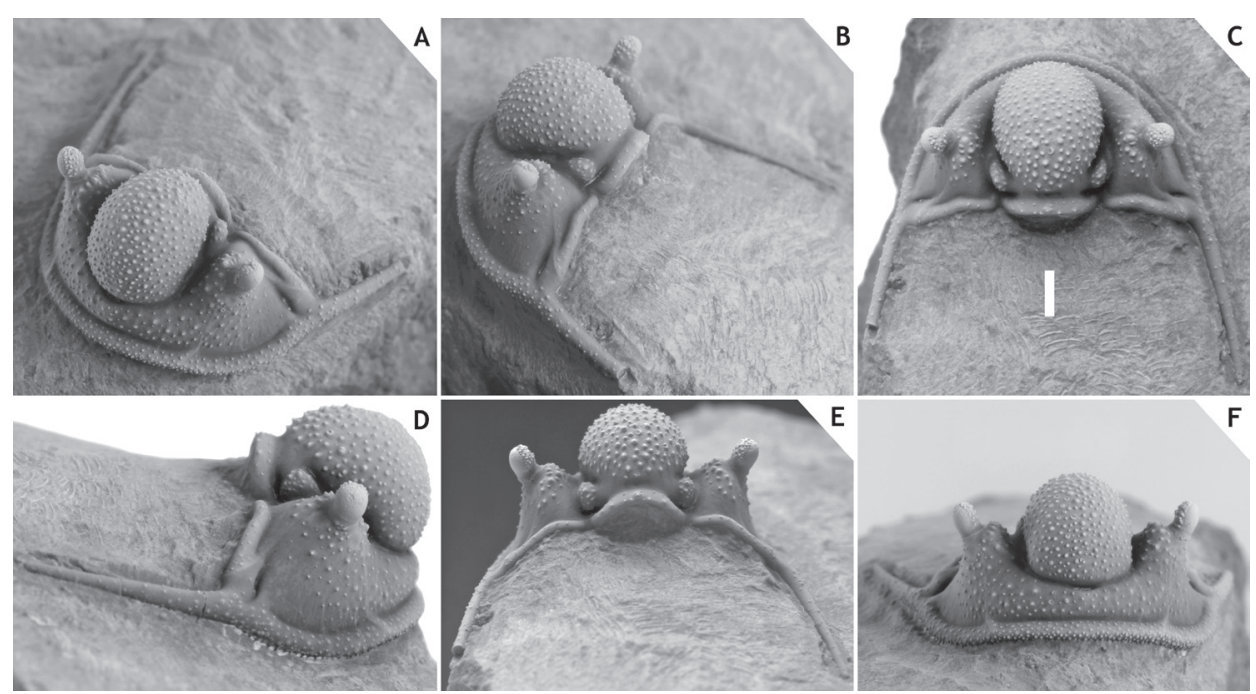

Figure 24. Cyphaspis khraidensis sp. nov. from ZGEE2, Timrhanrhart Formation, at Khraid, upper Emsian, Morocco. Holotype cephalon IRSNB a13004, in oblique anterolateral (A), oblique posterolateral (B), dorsal (C), lateral (D), posterior (E), anterior $(\mathrm{F})$ views. Scale bar is $2 \mathrm{~mm}$. 

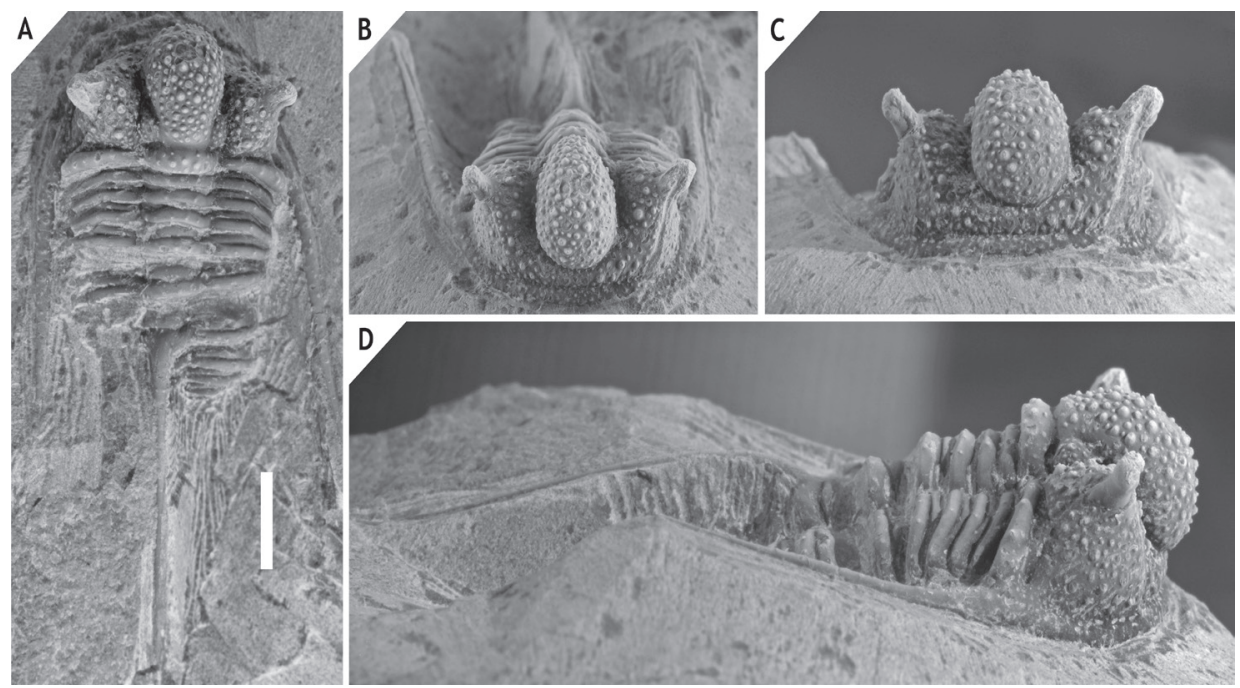

Figure 25. Cyphaspis cf. khraidensis sp. nov., presumably from the Emsian at Issoumour1, Morocco. Complete specimen IRSNB a13006, in oblique dorsal (A), oblique anterior (B), anterior (C), lateral (D) views. Scale bar is 5 $\mathrm{mm}$.

distinctive morphology including the fine and densely spaced ornament, much more inflated median glabellar lobe, and tiny eyes warrant the description of C. khraidensis as a distinct species.

\section{Cyphaspis cf. khraidensis sp. nov.}

(Fig. 25)

Material. IRSNB a13006, a complete specimen from the Emsian? at the Issoumour1 locality, Morocco.

Discussion. A single specimen from Issoumour1 was obtained from workers but the stratigraphic origin is not known exactly. Its cephalon can only be discriminated from $C$. khraidensis through its coarser grained prosopon. A tentative Emsian age is inferred from the morphological similarities between these two taxa.

\section{Cyphaspis tadachachtensis sp. nov.}

Etymology. Named after its geographic occurrence.

\section{Holotype. IRSNB a13002, incomplete cephalon.}

Type locality and horizon. Tadachacht locality, Morocco; Khebchia Formation, basalmost upper Emsian.

Diagnosis. Member of the agayuara group with cephalon bearing large, cone-shaped tubercles on median glabellar lobe, L1 and fixigenae; large L1 and Fx4; tubercles are ubiquitous on preglabellar and librigenal fields.

Discussion. Cyphaspis tadachachtensis is a very rare species that co-occurs in Tadachacht with $C$. lerougei. It is similar to $C$. agayuara from Zguilma and Talawarite yet distinct in several important aspects: the median glabellar lobe is less inflated; L1 is larger; the cephalic ornament is generally much denser, especially on the preglabellar and librigenal fields. We are hopeful that future collections at the type locality will yield more material.

\section{Cyphaspis ihmadii sp. nov.}

(Fig. 27)

\section{Etymology. Named after Ibrahim Ihmadi.}

\section{Holotype. IRSNB a13021, complete specimen.}

Type locality and horizon. Issoumour2 locality, Morocco; lower "Radiaspis couche", Bou Dîb Formation, Givetian.

Diagnosis. Member of the agayuara group with posterior part of L1 connected to median glabellar lobe; interocular fixigena bears a narrow, distinctly swollen area that curves backward and outward following the contour of the eye; median glabellar lobe and even preglabellar field overhang cephalic margin; librigenal field bears several randomly scattered tubercles; long, thin, proximally outward curved, distally posteriorly directed genal spines; large pygidium; posterior tegimen developed as a thick, uniform blanket, covering about two third of the pygidium; anterior margin of posterior tegimen accentuated by a row of dense ornament that runs from the third pygidial axial ring across the pleural fields and onto the $9^{\text {th }}$ thoracic pleural tip.

Description. Scantily ornamented cephalon with the exception of median glabellar lobe and fixigenae; long (tr.) border furrows of fixigena and librigena so that at some point they both cross an imaginary exsagittal line just
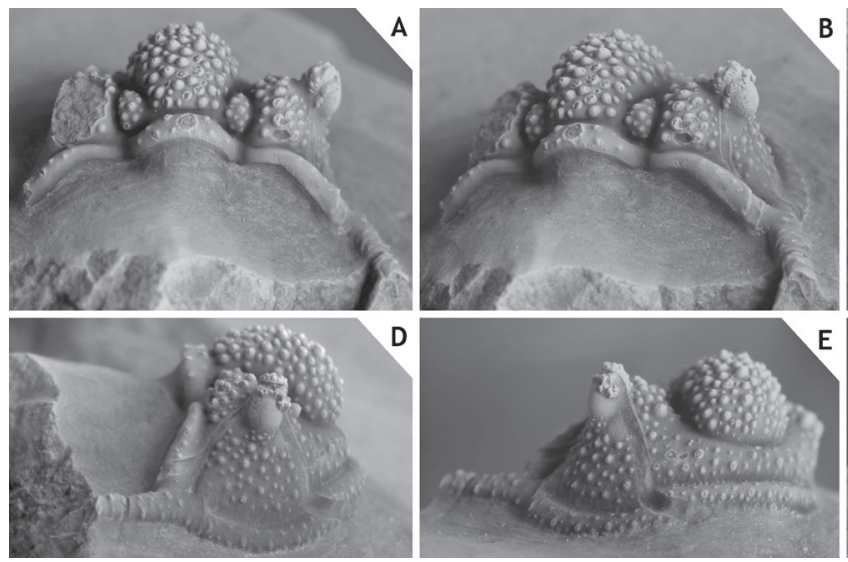

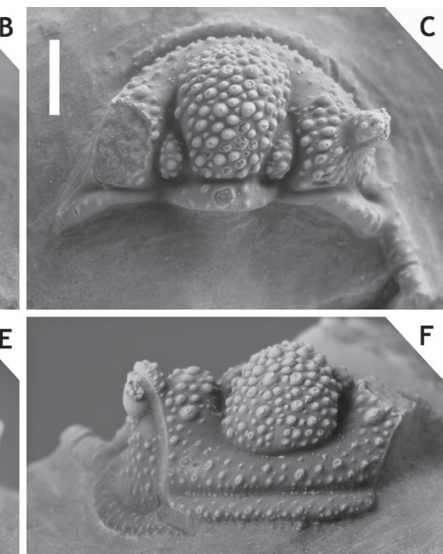

Figure 26. Cyphaspis tadachachtensis sp. nov. from the Khebchia Formation, at Tadachacht, upper Emsian, Morocco. Holotype incomplete cephalon IRSNB a13002, in posterior (A), oblique posterior (B), dorsal (C), lateral (D), anterolateral (E), anterior (F) views. Scale bar is $2 \mathrm{~mm}$. 


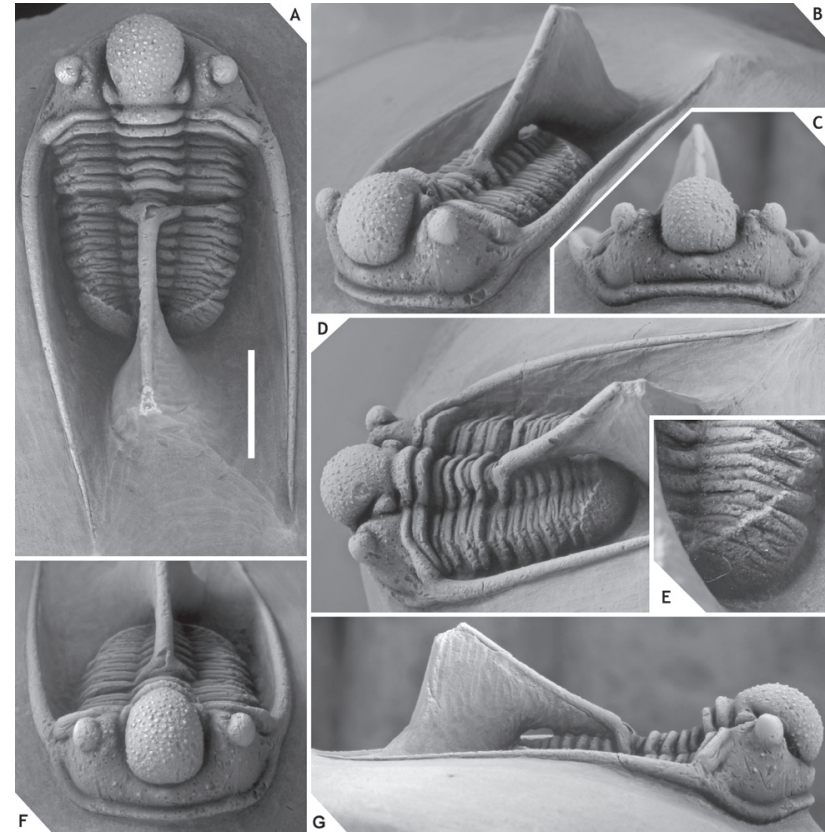

Figure 27. Cyphaspis ihmadii sp. nov. from the lower "Radiaspis couche", Bou Dîb Formation, at Issoumour2, Givetian, Morocco. Holotype complete specimen IRSNB a13021, in dorsal (A), oblique anterolateral (B), anterior (C), oblique lateral (D), close-up of pygidium $(\mathrm{E})$, oblique anterior $(\mathrm{F})$, lateral $(\mathrm{G})$ views. Scale bar is $5 \mathrm{~mm}$.

abaxial of the eye; anterior border of cranidium remains horizontal (anterior view) whereas the juxtaposed librigenal border is distinctly ventrally curved. Thorax bears few, randomly scattered granules; a long, proximally posteriorly and distally upward directed spine is developed on the sixth axial ring. Pygidium is widely rounded, rather large for a member of the group; three pygidial axial rings and pairs of pleurae (remaining rings and pleurae are obscured by the thick posterior tegimen).

Discussion. Cyphaspis ihmadii is one of the stratigraphically highest members of the agayuara group. Although its cephalic morphology is generally similar to that of Early Devonian members of the group C. ihmadii demonstrates a derived morphology (e.g. partially isolated L1; exceptionally strongly overhanging median glabellar lobe; large pygidium).

\section{Uncertain group}

\section{Cyphaspis sp. J}

(Fig. 2)

Material. IRSNB a13022, internal and external moulds of a complete specimen (plus silicone cast) from the Chavées Member, Jemelle Formation at the Jemelle locality, middle Eifelian, Belgium.

Discussion. This specimen serves as a typical example of a tectonically distorted trilobite from the Devonian in the Ardennes. It eloquently demonstrates that despite its completeness and the fair amount of details visible on the silicone cast, tectonic deformation can easily obscure important features such as cephalic and especially glabellar inflation. For this reason we have chosen to treat it in open nomenclature. Cyphaspis sp. J may qualify as a member of the agayuara group. It could just as well be a ceratophthalmus group member (based on the similarities between the pygidia of $C$. sp. $\mathrm{J}$ and $C$. ceratophthalmus); in that case it would probably be a synonym of $C$. sp. B of van Viersen \& Prescher (2007), a species from the same locality which is similar to C. ceratophthalmus.

\section{Acknowledgements}

G. Heumann and G. Oleschinski (Steinmann Institute, Bonn) traced type material and provided new photographs of trilobites in their care. M. Basse and Z. Smeenk authorised the reproductions of photos from their publications. E. Bonino, A. van Rossum and B. Schoenemann donated trilobite material for study. M. Walter and P. Hille shared information about trilobites in their collections. F. Lerouge and J. Koppka participated in discussions on some of the fossil localities in Morocco. J. Jagt and F. Lerouge helped to improve the manuscript. DH would like to thank H. Ait Hassain and A. Koumali for much appreciated support during field excursions in Morocco. The manuscript benefited from the astute review comments of M. Basse and A. Bignon.

\section{References}

Adrain, J.M. \& Chatterton, B.D.E., 1994. The aulacopleurid trilobite Otarion, with new species from the Silurian of northwestern Canada. Journal of Paleontology, 68, 305-323.

Adrain, J.M. \& Chatterton, B.D.E., 1995. The otarionine trilobites Harpidella and Maurotarion, with new species from northwestern Canada, the United States, and Australia. Journal of Paleontology, 69, 307-326.

Adrain, J.M. \& Chatterton, B.D.E., 1996. The aulacopleurid trilobite Cyphaspis, with new species from the Silurian of northwestern Canada. Journal of Paleontology, 70, 100-110.

Adrain, J.M. \& Kloc, G., 1997. Lower Devonian aulacopleuroidean trilobites from Oklahoma. Journal of Paleontology, 71, 703-712.

Alberti, G.K.B., 1969. Trilobiten des jüngeren Siluriums sowie des Unter- und Mitteldevons. I. Mit Beiträgen zur Silur-DevonStratigraphie einiger Gebiete Marokkos und Oberfrankens. Abhandlungen der Senckenbergischen Naturforschenden Gesellschaft, 520, 1-692.

Alberti, G.K.B., 1981. Beziehungen zwischen "herzynischen" Trilobiten-Faunen aus NW-Marokko und Deutschland (Unterund Mitteldevon). Natur und Museum, 111, 362-369.

Alberti, H., 1968. Trilobiten (Proetidae, Otarionidae, Phacopidae) aus dem Devon des Harzes und des Rheinischen Schiefergebirges (Beitrag I). Beihefte zum Geologischen Jahrbuch, 73, 1-147.

Angelin, N.P., 1854. Palaeontologia Scandinavica. Pars I. Crustacea formationis transitionis. Fasc. 2. Lund, i-ix + 21-92

Basse, M., 1997. Trilobiten aus mittlerem Devon des Rhenohercynikums: II. Proetida (2), Ptychopariida, Phacopida (1). Palaeontographica (A), 246, 53-142.

Basse, M., 2002. Eifel-Trilobiten. 1. Proetida. Goldschneck, Korb, 152 p.

Basse, M., 2003. Eifel-Trilobiten 2. Phacopida 1. Goldschneck, Korb, $198 \mathrm{p}$.

Basse, M., 2006. Eifel-Trilobiten IV. Proetida (3), Phacopida (3). Quelle \& Meyer, Wiebelsheim, 304 p.

Basse, M. \& Lemke, U., 1996. Trilobiten aus mittlerem Givetium (Mittel-Devon) des nördlichen Rechtsrheinischen Schiefergebirges. Geologie und Paläontologie in Westfalen, 46, 1-72.

Becker, R.T., Bockwinkel, J., Ebbighausen, V., Aboussalam, S.Z. Hassani, A. El, Nübel, H., 2004. Lower and Middle Devonian stratigraphy and faunas at Bou Tserfine near Assa (Dra Valley, SW Morocco). Documents de l'Institut Scientifique, Rabat, 19, 90-100.

Bronn, H.G., 1835-1837. Lethaea Geognostica, oder Abbildungen und Beschreibungen der für die Gebirgs-Formationen bezeichnendsten Versteinerungen. Schweizerbart, Stuttgart, 1346 p.

Bultynck, P. \& Hollard, H., 1980. Distribution comparée de Conodontes et Goniatites dévoniens des plaines du Dra, du Ma'der et du Tafilalt (Maroc). Aardkundige Mededelingen, 1, 8-73.

Burmeister, H., 1843. Die Organisation der Trilobiten aus ihren lebenden Verwandten entwickelt; nebst einer systematischen Übersicht aller seither beschriebenen Arten. Reimer, Berlin, 147 p.

Chatterton, B.D.E., Fortey, R.A., Brett, K.D., Gibb, S.L. \& McKellar, R.C., 2006. Trilobites from the upper Lower to Middle Devonian Timrhanrhart Formation, Jbel Gara el Zguilma, southern Morocco. Palaeontographica Canadiana, 25, 1-177.

Chlupáč, I. \& Kukal, Z., 1986. Reflection of possible global Devonian events in the Barrandian area, C.S.S.R. In Walliser, O. (ed.), Global Bio-events: a critical approach. Springer, Berlin, Lecture Note in Earth Sciences, 8, 169-179.

Coen-Aubert, M., Préat, A. \& Tourneur, F., 1986. Compte rendu de l'excursion de la Société belge de Géologie du 6 novembre 1985. Bulletin de la Société belge de Géologie, 95, 247-256.

Ebach, M.C., 2002. Lower Devonian trilobites from Cobar, New South Wales. Records of the Western Australian Museum, 20 353-378. 
Erben, H.K., 1953. Uber einige Otarionidae (Tril.) aus dem MittelDevon der Eifel. Senckenbergiana lethaea, 34, 73-80.

Franke, C., 2010. Marine Fauna der Wiltz-Schichten (Ober-Emsium, Unter-Devon) der Mulde von Wiltz und der Daleider MuldenGruppe (Luxemburg, Deutschland): Teil 1. In Franke, C. (ed.), Beiträge zur Paläontologie des Unterdevons Luxemburgs (2). Ferrantia, 58, 5-62.

García-Alcalde, J., 1997. North Gondwanan Emsian events. Episodes, $20,241-246$

García-López, S., Jahnke, H. \& Sanz-López, J., 2002. Uppermost Pridoli to Upper Emsian stratigraphy of the Alto Carrión Unit, Palentine Domain (Northwest Spain). In García-López, S. \& Bastida, F. (eds), Palaeozoic conodonts from Northern Spain. Instituto Geológico y Minero de España, serie Cuardernos del Museo Geominero, 1, 229-257.

Gibb, S.L. \& Chatterton, B.D.E., 2007. Timsaloproetus new genus (Proetida: Trilobita) and included species from Lower and Middle strata of southern Morocco. Journal of Paleontology, 81, 352-367.

Gibb, S.L. \& Chatterton, B.D.E., 2010. Gerastos (Order Proetida; Class Trilobita) from the Lower to Middle Devonian of the southern Moroccan Anti-Atlas region. Palaeontographica Canadiana, 30, 1-89.

Goldfuss, A., 1843. Systematische Übersicht der Trilobiten und Beschreibung einiger neuen Arten derselben. Neues Jahrbuch für Mineralogie, Geognosie, Geologie und Petrefaktenkunde, 1843, 537-567.

Haas, W., 1968. Trilobiten aus dem Silur und Devon von Bithynien (NW-Türkei). Palaeontographica (A), 130, 60-207.

Haas, W., 1982. Predvariteji'n'ie dann'ie po Devonu rayona k yugo-vostoku ot Stambujia (Turtsiya) [Preliminary notes of the Devonian SE of Istanbul (Turkey)]. In Sokolov, B.S. \& Rzhonsnitskaya, M.A. (eds), Biostratigrafiya pogranichnykh otlozheniy Nizhnego i Srednego Devona; Trudy polevoy sessii Mezhdunarodnoy Podkomissii po Stratigrafii Devona; Samarkand, 1978 [Biostratigraphy of Lower and Middle Devonian boundary deposits; Proceedings of field symposium of the International Subcommission on the Devonian Stratigraphy, Samarkand, USSR, 1978]. Akademiya Nauk SSSR, otdelenie geologii, geofiziki i geokhimii; Ministerstvo Geologii SSSR, Vsesoyuznyy Nauchno-Issledovatel'skiy Geologicheskiy Institut (VSEGEI), 144-147. [In Russian, with English summary]

Hughes, N.C. \& Chapman, R.E., 2001. Morphometry and phylogeny in the resolution of paleobiological problems - unlocking the evolutionary significance of an assemblage of Silurian trilobites. In Adrain, J.M., Edgecombe, G.D. \& Lieberman, B.S. (eds), Fossils, phylogeny and form: an analytical approach. Kluwer Academic/Plenum, New York, 29-54.

ICZN, 1987. Opinion 1434. Cyphaspis Burmeister, 1843 (Trilobita): Phacops ceratophthalmus Goldfuss, 1843, designated as type species. Bulletin of Zoological Nomenclature, 44, 134-135.

Jansen, U., Lazreq, N., Plodowski, G., Schemm-Gregory, M., Schindler, E. \& Weddige, K., 2007. Neritic-pelagic correlation in the Lower and basal Middle Devonian of the Dra Valley (Southern Anti-Atlas, Moroccan Pre-Sahara). In Becker, R.T. \& Kirchgasser, W.T. (eds), Devonian Events and Correlations. Geological Society, London, Special Publication, 278, 9-37.

Johnson, R.G. \& Fortey, R.A., 2012. Proetid trilobites from the Lower Devonian (Pragian) Ihandar Formation, Anti-Atlas, Morocco. Journal of Paleontology, 86, 1032-1050.

Johnson, J.G., Klapper, G. \& Sandberg, C.A., 1985. Devonian eustatic fluctuations in Euramerica. Geological Society of America Bulletin, 96, 567-587.

Khaldi, A.Y., Crônier, C., Hainaut, G., Abbache, A. \& Ouali Mehadji, A., 2016. A trilobite faunule from the Lower Devonian of the Saoura Valley, Algeria: biodiversity, morphological variability and palaeobiogeographical affinities. Geological Magazine, 153, 357-387.

Kielan, Z., 1954. Les trilobites mésodévoniens des Monts de SainteCroix. Palaeontologia Polonica, 6, 1-50.

Klug, C., De Baets, K., Naglik, C.J. \& Waters, J., 2014. A new species of Tiaracrinus from the latest Emsian of Morocco and its phylogeny. Acta Palaeontologica Polonica, 59, 135-145.

Kobayashi, T. \& Hamada, T., 1977. Devonian trilobites of Japan in comparison with Asian, Pacific and other faunas. Palaeontological Society of Japan, Special Paper, 20, 1-202.

Kowalski, H., 1990. Trilobiten aus dem Devon der Eifel. Der Aufschluss, Sonderband, 33, 11-63.

Le Maître, D., 1952. La faune du Dévonien inférieur et moyen de la Souara et des abords de l'Erg El Djemel (Sud Oranais). Matériaux pour la Carte géologique de l'Algérie. 1'ere série, paléontologie, 12, $1-170$.

Lebrun, P. \& Viersen, A.P. van, 2015. Trilobites du Dévonien Moyen dans la carrière de Resteigne (Belgique). Fossiles, Revue française de Paléontologie, 24, 25-28.
Lieberman, B.S. \& Kloc, G.J., 1997. Evolutionary and biogeographic patterns in the Asteropyginae (Trilobita, Devonian) Delo, 1935. Bulletin of the American Museum of Natural History, 232, 1-127.

McKellar, R.C. \& Chatterton, B.D.E., 2009. Early and Middle Devonian Phacopidae (Trilobita) of southern Morocco. Palaeontographica Canadiana, 28, 1-109.

Morzadec, P., 1981. Les trilobites. In Morzadec, P., Paris, F. \& Racheboeuf, P.R. (eds), La tranchée de la Lézais, Emsien supérieur du Massif armoricain. Mémoires de la Société Géologique et Minéralogique de Bretagne, 27, 279-287.

Morzadec, P., 1983. Trilobites du Dévonien (Emsien-Famennien) de la Rade de Brest (Massif Armoricain). Palaeontographica (A), $181,103-184$

Morzadec, P., 2001. Les trilobites Asteropyginae du Dévonien de l'Anti-Atlas (Maroc). Palaeontographica (A), 262, 53-85.

Plusquellec, Y., 2007. Histoire naturelle des Pleurodictyformes (Cnidaria, Tabulata, Dévonien) du Massif armoricain et des régions Maghreboeuropéennes principalement. Mémoires de la Société Géologique et Minéralogique de Bretagne, 32, 1-138.

Přibyl, A. \& Vaněk, J., 1981. Studie zur Morphologie und Phylogenie der Familie Otarionidae R. \& E. Richter, 1926 (Trilobita). Palaeontographica (A), 173, 160-208.

Ramsköld, L. \& Chatterton, B.D.E., 1991. Revision and subdivision of the polyphyletic 'Leonaspis' (Trilobita). Transactions of the Royal Society of Edinburgh: Earth Sciences, 82, 333-371.

Richter, R., 1909. Beiträge zur Kenntnis devonischer Trilobiten aus dem Rheinischen Schiefergebirge. Dissertation, Universität Marburg; printed by Gebrüder Knauer, Frankfurt am Main, 96 p.

Richter, R. \& Richter, E., 1926. Die Trilobiten des Oberdevons. Beiträge zur Kenntnis devonischer Trilobiten. IV. Abhandlungen der Preußischen Geologischen Landesanstalt, Neue Folge, 99, 1-314.

Rouault, M., 1851. Mémoire sur le terrain paléozoïque des environs de Rennes. Bulletin de la Société Géologique de France, 8, 358-399.

Schraut, G., 2000. Eine neue Unterart von Phacops (Phacops) sparsinodosus Struve 1970 aus dem Mittel-Devon von Marokko. Senckenbergiana lethaea, 80, 525-535.

Schraut, G. \& Feist, R., 2004. The Devonian styginid trilobite Paralejurus, with new data from Spain and Morocco. Journal of Paleontology, 78, 709-722.

Smeenk, Z., 1983. Devonian trilobites of the southern Cantabrian Mountains (northern Spain) with a systematic description of the Asteropyginae. Leidse Geologische Mededelingen, 52, 383-511.

Spriestersbach, J., 1919. Neue Versteinerungen aus dem Lenneschiefer. Jahrbuch der Preußischen Geologischen Landesanstalt, 38, 434-512.

Thomas, A.T., 1978. British Wenlock trilobites. Part 1. Palaeontographical Society Monograph, 552, 1-56.

Thomas, A.T. \& Owens, R.M., 1978. A review of the trilobite family Aulacopleuridae. Palaeontology, 21, 65-81.

Thomas, A.T. \& Owens, R.M., 1980. Cyphaspis Burmeister, 1843 (Trilobita): proposed designation of type species under the plenary powers. Z.N.(S.) 2257. Bulletin of Zoological Nomenclature, 37 , 122-123.

Vidal, M., Dabard, M.-P., Gourvennec, R., Le Hérissé, A., Loi, A., Paris, F., Plusquellec, Y. \& Racheboeuf, P.R., 2011. Le Palézoïque de la presqu'île de Crozon, Massif armoricain. Géologie de la France, 2011 (1), 3-45.

Viersen, A.P. van, 2006. New Middle Devonian trilobites from VireuxMolhain (Ardennes, northern France). Senckenbergiana lethaea, 86, 63-75.

Viersen, A.P. van, 2007. Preliminary report of trilobites from the Hanonet Formation (Eifelian - Givetian transition), southern border of the Dinant Synclinorium, Belgium. Bulletin de l'Institut royal des Sciences naturelles de Belgique, Sciences de la Terre, 77, 15-29.

Viersen, A.P. van \& Prescher, H., 2007. Note on Cyphaspis Burmeister 1843 (Trilobita, Aulacopleuridae), with a review of several species mainly from the Devonian of Belgium and Germany. Senckenbergiana lethaea, 87, 157-170.

Viersen, A.P. van \& Prescher, H., 2008. Devonian Proetidae (Trilobita) from the Ardennes Massif (Belgium, N France) and the Eifel Hills (W Germany). In Steurbaut, E., Jagt, J.W.M. \& Jagt-Yazykova, E.A. (eds), Annie V. Dhondt Memorial Volume. Bulletin de l'Institut royal des Sciences naturelles de Belgique, Sciences de la Terre, 78, 9-29.

Viersen, A.P. van \& Prescher, H., 2010. Taxonomy and biostratigraphy of some proetid trilobites in the Middle Devonian of the Ardennes and Eifel (Rhenohercynian Zone). Bulletin de l'Institut royal des Sciences naturelles de Belgique, Sciences de la Terre, $80,5-45$.

Viersen, A.P. van \& Prescher, H., 2011. New species of the lichid trilobite Ceratarges from the Middle Devonian in Morocco. Geologica Belgica, 14, 193-202. 
Viersen, A.P. van \& Prescher, H., 2014. "Devil horned" Cyphaspis (Trilobita, Otarioninae): examples from the Middle Devonian of the Ardennes (Belgium), Eifel (Germany) and Ma'der (Morocco). Geologica Belgica, 17, 268-275.

Viersen, A.P. van, Prescher, H. \& Savelsbergh, J., 2009. Description of two new trilobites from the Ahrdorf Formation (Middle Devonian) at the "Trilobitenfelder" of Gees, Eifel, Rhenish Mountains. Bulletin de l'Institut royal des Sciences naturelles de Belgique, Sciences de la Terre, 79, 43-53.

Zenker, J.C., 1833. Beiträge zur Naturgeschichte der Urwelt. Organische Reste (Petrefacten) aus der Altenburger Braunkohlen-Formation, dem Blankenburger Quadersandstein, jenaischen bunten Sandstein und böhmischen Übergangsgebirge. Jena, $67 \mathrm{p}$.

Manuscript received 26.11.2015, accepted in revised form 28.04.2016, available on line 05.07.2016.

The figures in full size are available online as supplementary materials (see http://popups.ulg.ac.be/1374-8505/index. php?id=5350 : GB 19-3-4 van Viersen \& Holland_Supplem. Mat.pdf). 